\title{
A review on treatment of acid mine drainage with waste materials: A novel approach
}

\author{
Sukla Saha and Alok Sinha* \\ Department of Environmental Science \& Engineering, Indian Institute of Technology (ISM) Dhanbad - 826004, Jharkhand, India \\ Received: 01/02/2018, Accepted: 17/9/2018, Available online: 26/09/2018 \\ *to whom all correspondence should be addressed: e-mail: aloksinha11@yahoo.com \\ https://doi.org/10.30955/gnj.002610
}

\section{Abstract}

The present study systematically and comprehensively reviewed different aspects of treating Acid Mine Drainage (AMD) with active treatment and waste materials. The work also critically reviews the status and the factors associated with the treatment process. Although, conventional active methods are very efficient but they are mainly associated with costly material as well as high maintenance cost which enhances the cost of entire treatment system. Waste materials such as fly ash, metallurgical slag, zero valent iron (ZVI), cement kiln dust (CKD), organic waste such as peat humic agent (PHA) and rice husk can be efficiently used for the treatment of AMD. However, efficiency of different waste material varied from each other due to the variation in their physical and chemical characteristics. The results from the investigation showed that fly ash, metallurgical slag and CKD raise the $\mathrm{pH}$ of acidic solution more, in comparison to $\mathrm{ZVI}$ and organic waste, due to their richness in lime content. Furthermore, fly ash can be efficiently converted and utilized in its other derivative such as chemically modified fly ash and zeolite. Efficiency of ZVI is hindered by the presence of higher concentration of total dissolved solids. PHA can treat AMD that is mild acidic in nature. Besides, long retention time is required for the removal of heavy metals and sulfur with organic waste and sulfate reducing bacteria (SRB). The study also potentially reviewed that metal removal from $A M D$ varied due to composition of AMD and the characteristics of waste materials. However, waste materials demand more attention for its practical applicability in field conditions due to its richness, higher possibility for recycling and reuse, low installation cost and harmless nature towards the environment.

Keywords: Acid Mine Drainage; Active Treatment; Fly Ash; Metallurgical Slag; Zero Valent Iron; Organic waste.

\section{Introduction}

Acid Mine Drainage (AMD) refers to the effluent generated from active as well as abandoned mines. The exposure of rocks consisting of ferrous or ferric sulfide minerals to water and oxygen results in generation of AMD.

The reason behind AMD generation is the presence of sulfide mineral, in form of iron sulfide-aggregated rocks and exposure of these minerals to water and oxygen (Akcil and Koldas, 2006).

This phenomenon is more prominent in abandoned mines than active mines, as in latter case water tables are kept low by continuous pumping system. However, in case of abandoned mines, pumping systems are disabled and the voids generated due to mining are filled with water. This water than reacts with the pyrite present in the rocks of these mines and generates acidic drainage, thereby contaminating the groundwater (Johnson and Hallberg, 2005; McCarthy, 2011). However, the reason behind the AMD production is not only restricted to the mining activities, it can also takes place in the highway, tunnel construction and other deep excavations. The primary and secondary sources of AMD are presented in Table 1 (Akcil and Koldas, 2006).

Table 1. Sources of Acid Mine Drainage (Akcil and Koldas, 2000)

\begin{tabular}{cc}
\hline Primary sources & Secondary sources \\
\hline Mine rock dump & Treatment sludge pounds \\
\hline Tailings impoundment & Rock cuts \\
\hline $\begin{array}{c}\text { Underground and open } \\
\text { pit mine workings }\end{array}$ & Concentrated load-out \\
\hline $\begin{array}{c}\text { Pumped/nature } \\
\text { discharged underground } \\
\text { water }\end{array}$ & Stockpiles \\
\hline $\begin{array}{c}\text { Diffuse seeps from } \\
\text { replaced overburden in } \\
\text { rehabilitated areas }\end{array}$ & Concentrate spills along roads \\
\hline $\begin{array}{c}\text { Construction rock used in } \\
\text { roads, dams etc. }\end{array}$ & Emergency ponds \\
\hline
\end{tabular}

Figure 1 illustrates the process of AMD generation. It shows that pyrite oxidation can take place through several pathways including surface interactions with dissolved $\mathrm{O}_{2}$, $\mathrm{Fe}^{3+}$, and other mineral catalysts such as $\mathrm{MnO}_{2}$ (Buzzi et al., 2013). Oxidation of pyrite $\left(\mathrm{FeS}_{2}\right)$ through (1(a) and $1(b))$ is key reaction for AMD generation. Pyritic oxidation 
leads to the formation of dissolved iron, sulfate and hydrogen (1).

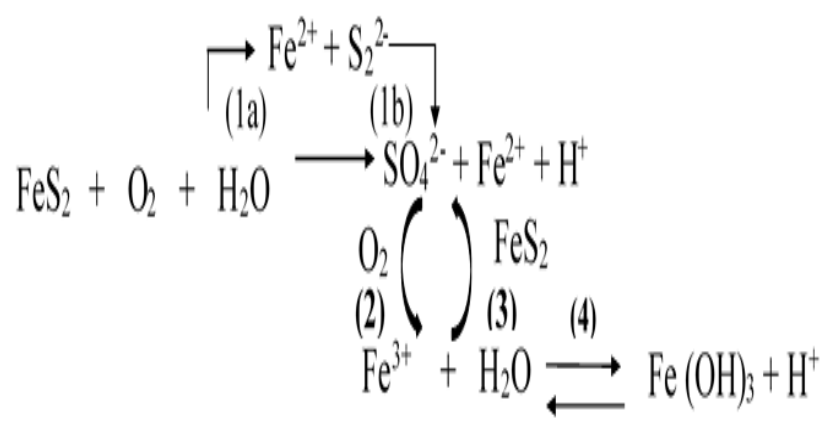

Figure 1. Model for oxidation of pyrite (Buzzi et al., 2013)

$\mathrm{Fe}^{2+}, \mathrm{SO}_{4}{ }^{2-}, \mathrm{H}^{+}$are dissolved into the drainage and act as the key indicator for the increasing total dissolved concentration of metals and acidity of the drainage. $\mathrm{H}^{+}$ helps to reduce the $\mathrm{pH}$ of the drainage. $\mathrm{Fe}^{2+}$ undergoes further oxidation (2) if there is favorable oxidizing condition prevails in terms of oxygen concentration, $\mathrm{pH}$, and microbial activity (Akcil and Koldas, 2006). Ferric iron precipitates as ferric hydroxide $\left(\mathrm{Fe}(\mathrm{OH})_{3}\right)$ and jarosite if the $\mathrm{pH}$ value of the reaction lies between 2.3-3.5 (4) (Akcil and Koldas, 2006; Simate and Ndlovu, 2014). Ferric hydroxide, so formed, is not stable when the solution $\mathrm{pH}$ is less than 2, and $\mathrm{Fe}^{3+}$ remains in the solution (Dold, 2010). Remaining $\mathrm{Fe}^{3+}$ present in the solution, that cannot be converted into ferric hydroxide (precipitated) form, acts as an oxidizing agent for further pyrite oxidation through (3) (Akcil and Koldas, 2006). $\mathrm{Fe}^{2+}$ produced from the similar reaction aids to continue the reaction (2) and (4) until entire ferric iron or pyrite is exhausted.

AMD is highly acidic in nature; $\mathrm{pH}$ ranges from 2-3 with elevated concentration of different heavy metals, ferrous and non-ferrous metal sulfate (McCarthy, 2011). Qualitative information about the nature of AMD can be identified through the visual examination of rock and effluent. Organic stains and cloudy water indicates about the presence of iron with $\mathrm{pH}$ value above 3.5 whereas wine-colored stains with clear effluent is strong indicator of iron with $\mathrm{pH}$ value less than 3.5. Presence of aluminium (Al) can be detected by white color stains with $\mathrm{pH}$ value above 4.5. However, chocolate brown to black stains clearly specify the presence of manganese in the effluent at a pH level greater than 7 (Fripp et al., 2000). Although the concentration of the metals and $\mathrm{pH}$ of the AMD varies, but sulfate concentration remains higher in all effluents generated from various mines.

It causes major environmental pollution. Approximately $7000 \mathrm{~km}$ of streams in Unites States of America (USA), was severely damaged by AMD; $8000-16000 \mathrm{~km}$ of streams in the USA are in worst condition and extremely contaminated by AMD (Acid report 2010; USEPA 1995). An investigation in metal mine and industrial-mineral tailings in Canada indicated that 6 billion tons of waste rock and 7 billion tons of tailings; 750 billion tons of waste rock and 1.9 billion tons of tailings respectively, have potential to generate acidic drainage (Acid report 2010). Groundwater present in the mining district of Johannesburg, South Africa is massively polluted and extremely acidified because of oxidation of pyrite present in mine tailings dumps (Naicker et al., 2003). Also, in the areas of Witwatersrand goldfield, which is also known as the rand, underground mine voids, surface mine tailings dumps, waste rocks, created in the course of mining, milling and processing of ores are the key source of acid mine drainage generation (Ochieng et al., 2010; Merkel and Mandy, 2011). Water pollution including AMD in Loskop Dam, Vaal river catchment and the Olifants River Catchment area, due to Mpumalanga coalmines, has been reported (Acid Report 2010; Manders et al., 2009; Merkel and Mandy, 2011). McCarthy et al. (2011) also reported that acidic drainage from Witbank and Middelburg coalmines contaminated the tributaries of the Olifants river. In India, Makum coal fields in Assam, Jaintia coalfield in Meghalaya, Western Coalfield (WCL), Northern Coalfiled (NCL), north-eastern coalfield are prone to generate AMD by the oxidation of pyrite present in coals (Baruah et al., 2006; Equeenuddin et al., 2010; Sahoo et al., 2012; Tiwary, 2001).

If this acidic drainage is not treated then it can contaminate the surface as well as ground water, destroy the plant, aquatic and human life. AMD has severe negative impact on the environment. Therefore, AMD must be treated to ensure the safety and to minimize the environment and health risk.

Treatment of AMD is divided into two categories, i.e. active and passive. To adopt the treatment options, economic factors and technical factors are always considered. Economic factor comprises of price of reagents, labor, machineries, equipment, time scale for treatment and rate of interest. Technical factors include acidity levels, influent flow, type and concentration of heavy metals present in AMD wastewater (Skousen et al., 2000). Active treatment refers to the continuous application of alkaline materials into the drainage water to neutralize acidic mine waters and to precipitate metals. Whereas, passive treatment is the process where natural and constructed wetlands are used to treat the acidic drainage (Johnson and Hallberg, 2005).

This manuscript critically reviews different active treatment methods that uses waste materials as the main component in the process. It also provides a comparative analysis among different waste materials with respect to metal percentage removal efficiency and a detailed knowledge about the waste materials that can be used successfully for the treatment of AMD.

\section{Treatment technology for AMD}

Owing to the difficulties in controlling the AMD at source, it is rather an alternative approach to collect and treat $A M D$, thereby minimizing the impact of $A M D$ on receiving streams, river and other environmental components. 


\subsection{Active treatment}

The most extensively used methodology to mitigate AMD is active treatment that includes various processes such as aeration, addition of neutralizing agents, reverse osmosis, ion exchange, electro dialysis and natural zeolites (Ali, 2011).

Aeration is done to introduce air into water, which facilitates the oxygen to combine with metals and forms metal oxides, which gets precipitated. Different type of aerators are available for this process, but mechanical surface aerators are used for hydrated lime treatment plants for the treatment of highly acidic and reduced water. Mechanical surface aeration helps to incorporate oxygen into water by rotating its blades located beneath the water in aeration basins. Aerator creates turbulence that disperses air bubbles and keeps the iron floc in suspension. High velocity spray nozzles are used for in-line aerators to improve the contact between air and water. However, the efficiency of aeration in terms of ferrous ion oxidation depends on $\mathrm{pH}$, as inorganic oxidation reaction is slow below $\mathrm{pH}$ 5. Therefore, this oxidation process is combined with the addition of base, to neutralize $\mathrm{pH}$ (Skousen et al., 1998; Skousen et al., 2000).

For neutralization and treatment of AMD, some chemicals such as limestone, hydrated lime, pebble quick lime, soda ash briquettes, caustic soda, ammonia, magnesium hydroxide, magna lime are widely used. Enhancement of $\mathrm{pH}$ of the solution to precipitate the insoluble metals as hydroxides or carbonates and for rapid chemical oxidation of ferrous iron is done by providing sufficient amount of alkalinity in the solution. Most of the metal ions except $\mathrm{Fe}^{3+}$, precipitate from water in a $\mathrm{pH}$ range of 6-9. Therefore, appropriate neutralizing agents are chosen for specific condition. Table 2 summarizes the characteristics as well as the advantages-disadvantages of using different neutralization materials.

Figure 2 shows conventional treatment plant that uses lime for the treatment of AMD (Aubé and Eng, 2004). Lime is added to the reactor filled with AMD to enhance the $\mathrm{pH}$ of $\mathrm{AMD}$ which facilitates the precipitation of metals present in AMD. Than flocculent is added and stirred into flocculent reactor to encourage the floc formation and enhance the settling rate of the precipitated metals in form of larger particles. Than the treated water is taken out from the flocculent reactor and sludge disposed of.

AMD when treated by reverse osmosis produces high quality effluent water which is suitable for potable or industrial use, while the concentrated acidic brine solution left behind contains Fe and sulfate (Skousen et al., 1998). Ultra Pressure Reverse Osmosis (ULPRO) attains 97\% and $96 \%$ rejections of heavy metal and total conductivity in comparison to Nano filtration (NF) with $90 \%$ and $48 \%$ rejection, respectively (Zhong et al., 2007). However, the major disadvantage of this process is less water recovery efficiency (13.8\%-15.3\%). High pressure is essential for more water recovery, which in turn enhances treatment cost. Researchers have also reported about the fouling of membrane for longer operational time. Moreover, this process is only useful for the AMD laden with low metal concentrations. Therefore, the applicability of RO and nanofiltration needs to be investigated further for the treatment of AMD with high metal concentrations as well as requirement for the pre or post treatment or another stage of reverse-osmosis treatment for complying the environmental standards (Sastri, 1979).

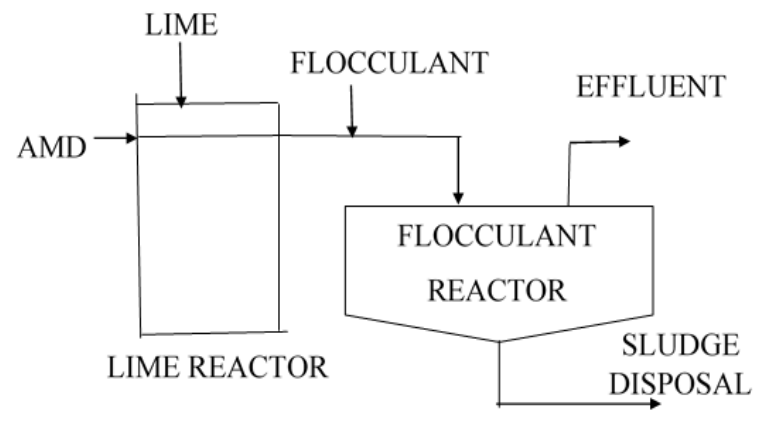

Figure 2. Conventional AMD treatment plant

Ion exchange is the reversible interchange of ions between a solid medium and the aqueous solution. Ion exchange resins or materials comprise of chemically inert polymer matrix with functional groups that are anionic or cationic. For treatment of hard water, water is passed through a bed of ion exchange material, which is charged with monovalent cations, such as sodium. Treatment of South African gold mines acidic drainage was done by heavy metal precipitation using lime followed by ion exchange for calcium and magnesium with sodium ions. (Skousen et al., 1998; Feng et al., 2000). Although, ionexchange generates $98 \%$ water recovery, but it requires some pre-treatment that increases the cost of treatment process. Feng et al. (2000) reported that an ion exchange plant with a capacity $2.5 \mathrm{ML} / \mathrm{d}$ treating $\mathrm{AMD}$ effluent, requires $2.5 \mathrm{~kg} / \mathrm{m}^{3}$ acid for regeneration of resin, 2.5 $\mathrm{kg} / \mathrm{m}^{3}$ of lime and produces $98 \%$ of water recovery. For the whole operation, estimated cost is US\$0.40/ $\mathrm{m}^{3}$. On other side, Gaikwad et al. (2010) carried out the performance and design of ion exchange column treating the AMD contaminated with copper. It was evaluated that for treatment of $5.137 \times 10^{-3} \mathrm{~m}^{3} /$ cycle of water and resin capacity of $36 \mathrm{~kg} / \mathrm{m}^{3}$, required $9.8175 \times 10^{-4} \mathrm{~m}^{3}$ of resin. It was also reported that the diameter of the ion-exchange column was approximately $0.05 \mathrm{~m}$ and the amount of water required for backwashing was $0.4594 \mathrm{~m}^{3} / \mathrm{hr}$.

Electrodialysis (ED) unit consists of number of narrow compartments separated by closely spaced membranes and its each compartment is divided with cation and anion membranes. Positive and negative electrodes are placed at extreme opposite end of the unit. After filling the channels with solution, electrodes are energized and the ions in solution migrate towards the charged poles and ions are collected on the membranes (Skousen et al., 1998, Buzzi et al., 2011). Buzzi et al. (2013) has studied the effectiveness of electrodialysis for the pretreated acidic drainage with microfiltration. However, if AMD contains $\mathrm{Fe}$, than it forms a precipitates at the surface of cation- 
exchange membranes, which requires increase of membrane voltage in continuous manner. Therefore, removal of $\mathrm{Fe}$ is considered as a pre-treatment for ED process to treat the acidic water.

Table 2. Characteristics of different neutralization materials used for the treatment of AMD

\begin{tabular}{|c|c|c|c|c|c|c|}
\hline SI. No. & $\begin{array}{l}\text { Name of acid } \\
\text { neutralization }\end{array}$ & $\begin{array}{c}\text { Saturation } \\
\text { pH }\end{array}$ & $\begin{array}{l}\text { Solubility } \\
\text { (mg/L) in } \\
\text { cold water }\end{array}$ & Advantage & Disadvantage & References \\
\hline 1. & Limestone & $8-9.4$ & 14 & $\begin{array}{l}\text { Inexpensive } \\
\text { material, safe } \\
\text { and easy to } \\
\text { handle }\end{array}$ & $\begin{array}{l}\text { Low solubility in } \\
\text { cold water, } \\
\text { generate external } \\
\text { coating or } \\
\text { armouring }\end{array}$ & $\begin{array}{l}\text { Skousen et al. } \\
\text { (1996); Skousen } \\
\text { et al. (1998); } \\
\text { Skousen (2002); } \\
\text { Taylor et al. } \\
\text { (2005) }\end{array}$ \\
\hline 2. & Hydrated Lime & 12.4 & $1300-1850$ & $\begin{array}{l}\text { Cost effective } \\
\text { reagent for } \\
\text { high flow and } \\
\text { highly acidic } \\
\text { AMD solution }\end{array}$ & $\begin{array}{l}\text { Being hydrophobic, } \\
\text { it requires } \\
\text { mechanical aerator } \\
\text { for mixing }\end{array}$ & $\begin{array}{c}\text { Skousen et al. } \\
\text { (1996); Skousen } \\
\text { et al. (1998); } \\
\text { Skousen (2002); } \\
\text { Taylor et al. } \\
\text { (2005) }\end{array}$ \\
\hline 3. & $\begin{array}{c}\text { Pebble Quick } \\
\text { Lime }\end{array}$ & 12.4 & $1300-1850$ & $\begin{array}{c}\text { Cost effective } \\
\text { neutralizing } \\
\text { agent }\end{array}$ & $\begin{array}{l}\text { It is very reactive, so } \\
\text { metering } \\
\text { equipment needed } \\
\text { to ensure proper } \\
\text { mixing }\end{array}$ & $\begin{array}{c}\text { Skousen et al. } \\
\text { (1996); Skousen } \\
\text { et al. (1998); } \\
\text { Skousen (2002); } \\
\text { Taylor et al. } \\
\text { (2005) }\end{array}$ \\
\hline 4. & $\begin{array}{l}\text { Soda Ash } \\
\text { Briquettes }\end{array}$ & 11.6 & 75,000 & $\begin{array}{l}\text { Useful for low } \\
\text { flow and low } \\
\text { amounts of } \\
\text { acidity and } \\
\text { metals }\end{array}$ & $\begin{array}{l}\text { Soda ash briquettes } \\
\text { absorbs moisture, } \\
\text { expand and thereby } \\
\text { stick to the corners } \\
\text { of hopper in basket- } \\
\text { hopper system. }\end{array}$ & $\begin{array}{c}\text { Skousen et al. } \\
\text { (1996); Skousen } \\
\text { et al. (1998); } \\
\text { Skousen (2002); } \\
\text { Taylor et al. } \\
\text { (2005) }\end{array}$ \\
\hline 5. & Caustic Soda & 14 & 450,000 & $\begin{array}{l}\text { Can be used in } \\
\text { remote } \\
\text { location } \\
\text { Very soluble } \\
\text { and easily } \\
\text { disperse in } \\
\text { water }\end{array}$ & $\begin{array}{l}\text { Incurred high cost, } \\
\text { not safe to handle } \\
\text { and generates high } \\
\text { sludge volume }\end{array}$ & $\begin{array}{l}\text { Skousen et al. } \\
\text { (1996); Skousen } \\
\text { et al. (1998); } \\
\text { Skousen (2002); } \\
\text { Taylor et al. } \\
\text { (2005) }\end{array}$ \\
\hline 6. & Ammonia & 9.2 & 900,000 & $\begin{array}{l}\text { Reactive and } \\
\text { easily soluble } \\
\text { Incurred 50- } \\
70 \% \text { less cost } \\
\text { than caustic } \\
\text { soda }\end{array}$ & $\begin{array}{l}\text { Cannot be handle } \\
\text { easily, increasing } \\
\text { the concentration of } \\
\text { hazardous nitrate, } \\
\text { specialized persons } \\
\text { are required for safe } \\
\text { handling of } \\
\text { ammonia }\end{array}$ & $\begin{array}{c}\text { Skousen et al. } \\
\text { (1996); Skousen } \\
\text { et al. (1998); } \\
\text { Skousen (2002); } \\
\text { Taylor et al. } \\
\text { (2005) }\end{array}$ \\
\hline 7. & $\begin{array}{l}\text { Magnesium } \\
\text { Hydroxide }\end{array}$ & $9.5-10.8$ & $1-50$ & $\begin{array}{l}\text { Cost effective } \\
\text { reagent for } \\
\text { high flow and } \\
\text { highly acidic } \\
\text { AMD solution }\end{array}$ & $\begin{array}{l}\text { Being hydrophobic, } \\
\text { it requires } \\
\text { mechanical aerator } \\
\text { for mixing }\end{array}$ & $\begin{array}{l}\text { Skousen et al. } \\
\text { (1996); Skousen } \\
\text { et al. (1998); } \\
\text { Skousen (2002); } \\
\text { Taylor et al. } \\
\text { (2005) }\end{array}$ \\
\hline 8. & Magna Lime & $9.5-10.8$ & $1-50$ & $\begin{array}{c}\text { Cost effective } \\
\text { neutralizing } \\
\text { agent }\end{array}$ & $\begin{array}{l}\text { It is very reactive, so } \\
\text { metering } \\
\text { equipment needed } \\
\text { to ensure proper } \\
\text { mixing } \\
\text { Dissolution kinetics } \\
\text { is marginally lower } \\
\text { than quick lime. }\end{array}$ & $\begin{array}{c}\text { Skousen et al. } \\
\text { (1996); Skousen } \\
\text { et al. (1998); } \\
\text { Skousen (2002); } \\
\text { Taylor et al. } \\
\text { (2005) }\end{array}$ \\
\hline
\end{tabular}


Zeolites are known to be naturally occurring hydrated aluminosilicate minerals. They are closely related to the group of minerals known as "tectosilicates". The formation of natural zeolites is due to alteration of glass rich volcanic rocks by fresh water or by seawater. Threedimensional frameworks of $\mathrm{SiO}_{4}$ and $\mathrm{AlO}_{4}$ formed the backbone of zeolite structure. Size of aluminium ion is very tiny to occupy the central position of the tetrahedron of four oxygen atoms, and the isomorphous replacement of $\mathrm{Si}^{4+}$ by $\mathrm{Al}^{3+}$, which in turn produce negative charge in the lattice. This net negative charge is balanced with the exchangeable cation (sodium, potassium or calcium). Cations are also interchangeable with some cations that are present in the solution $\left(\mathrm{Pb}^{2+}, \mathrm{Cd}^{2+}, \mathrm{Zn}^{2+}\right.$, and $\left.\mathrm{Mn}^{2+}\right)$. The best part in case of zeolite is ions, which are exchangeable and comparatively harmless which makes them a suitable component for treating the heavy metal laden wastewater (Erdem et al., 2004).) Adsorption rate of heavy metal ions from solution follow the progression: $\mathrm{Fe}^{3+}>\mathrm{Zn}^{2+}>\mathrm{Cu}^{2+}>\mathrm{Mn}^{2+}$ (Motsi et al., 2009). However, the efficiency of natural zeolites is exhausted after few adsorption cycles. Table 3 summarizes the advantage and the difficulties associated with reverse osmosis, ion exchange, electrodialysis and natural zeolites during treatment of acid mine water.

\subsection{Treatment of $A M D$ with waste materials}

The above mentioned chemical treatments for the neutralization of AMD are associated with high cost of the adsorbents. Besides this, armoring of limestone by ferric hydroxides is a major issue which hinders the treatment efficiency of oxic limestone drains and the active limestone treatment systems. All these difficulties lead researchers to find efficient and cost effective neutralization materials (Gitari et al., 2008). Extensive research has been done for the treatment of AMD by various industrial wastes such as fly ash, steel slag, ZVI, $C K D$, organic waste through combination of reactions such as neutralization, adsorption and precipitation.

\subsubsection{Fly ash}

Fly ash is a low cost, environment friendly, unconventional and alternative adsorbent for activated carbon (Ceptin and Pehlival, 2007). It can remove different heavy metals from wastewater (Polat et al., 2002; Erol et al., 2005; Heechan et al., 2005). Researchers have reported that it can be used as pretreatment agent as an alternative to dolomite and limestone (Potgieter-Vermaak et al., 2006). It has been extensively used for the treatment of AMD. It was reported that fly ash can decontaminate the acidic water by removing heavy metals such as iron (Fe), aluminium (Al), manganese (Mn), calcium (Ca), magnesium (Mg), zinc ( $\mathrm{Zn})$, copper $(\mathrm{Cu})$, cadmium (Cd), nickel (Ni), and cobalt (Co) (Gitari et al., 2008; Reynolds, 2004; Bäckström and Smarts, 2011; Jianping and Haito, 2014; Pradhan and Deshmukh, 2008). Removal percentage of different heavy metals with fly ash is presented in Table 4. Iron removal takes place at $\mathrm{pH}$ greater than 7. If the solution has $\mathrm{pH}$ from $4-4.5, \mathrm{Fe}^{3+}$ is removed as $\mathrm{Fe}(\mathrm{OH})_{3}$ and as schwertmannite $\left(\mathrm{Fe}_{8} \mathrm{O}_{8}(\mathrm{OH})_{6}\left(\mathrm{SO}_{4}\right) \cdot \mathrm{nH}_{2} \mathrm{O}\right)$. For aluminium $(\mathrm{Al})$ at $\mathrm{pH}$ 3.965.9 , jurbanite controlled the $\mathrm{Al}$ concentration at the beginning stages of the neutralization process (Gitari et al., 2008). Although, many researchers have reported higher removal percentage of $\mathrm{Cu}, \mathrm{Zn}$ and $\mathrm{Cd}$ (Gitari et al., 2008; Reynolds, 2004; Bäckström and Sartz, 2011) but low percentage removal of $\mathrm{Cu}, \mathrm{Zn}$ and $\mathrm{Cd}$ was also reported (Jianping and Haito, 2014). The differences in removal efficiency is attributed to the characteristics of the fly ash. Fly ash utilized by Gitari et al. (2008) and Reynolds (2004) was rich in calcium content ( $\mathrm{CaO} 2.1-8.43 \%$ ) than the fly ash used by Jianping and Haito (2014) (CaO 1.22\%). However, higher content of magnesium oxide (MgO $2.67 \%$ ), was found for the fly ash used by Gitari et al. (2008) in comparison to the fly ash utilized by Reynolds (2004) and Jianping and Haito (2014). Therefore, CaO content plays the major role for enhancing the $\mathrm{pH}$ of the solution and thereby removal of metals from the solution. Precipitation of different metals from the solution occur at different $\mathrm{pH}$. Manganese oxide $\left(\mathrm{Mn}^{2+}\right)$ at $\mathrm{pH}$ 5-5.5 and $\mathrm{Cu}$ and $\mathrm{Zn}$ at $\mathrm{pH}$ greater than 5-5.5 are cemented on the precipitated aluminium (oxy) hydroxide and iron (oxy) hydroxides. The concentration of $\mathrm{Ca}$ and $\mathrm{Mg}$ initially increases in the solution due to the leaching of $\mathrm{Ca}^{2+}$ and $\mathrm{Mg}^{2+}$ from surface of fly ash. However, after initial increment, Ca concentration decrease due to formation of gypsum and anhydrite, which takes over the control of calcium concentration in the solution. Gypsum formation at $\mathrm{pH}>5.5$ and adsorption of high concentration of sulfate by iron hydroxides at $\mathrm{pH}>6.0$ are attributed for the reduction of sulfate in the solution (Gitari et al., 2008). Fly Ash is not only effective for the treatment of AMD but it is also efficient adsorbent for the treatment of circumneutral mine water (CMW) which, contains lower concentration of $\mathrm{Fe}$ and $\mathrm{Al}$ but rich in $\mathrm{Ca}$ and $\mathrm{Mg}$ (Madzivire et al., 2010). CMW is produced by AMD's partial neutralization due to the surrounding geology. This process also results in precipitation of some metals while sulfate get precipitates in the form of gypsum or adsorbed on precipitating metal hydroxides. However, unlike AMD treatment with FA which removes significant amount of sulfate, treatment of CMW with FA is not so effective at $\mathrm{pH}<10$. Treatment of CMW with FA followed by seeding of gypsum and amorphous $\mathrm{Al}(\mathrm{OH})_{3}$, at $\mathrm{pH} 12.25$, reduced sulfate concentration from $4800 \mathrm{ppm}$ to $1043 \mathrm{ppm}$ due to the dissolution of $\mathrm{CaO}$ from FA. $\mathrm{CaO}$ present in FA, dissolves and reacts with sulfate ions according to the Eq. (1) and Eq. (2) (Madzivire et al., 2010).

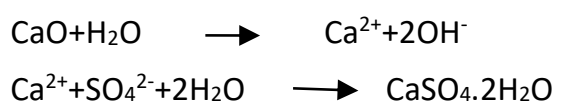

Thereafter, with addition of amorphous $\mathrm{Al}(\mathrm{OH})_{3}$, the sulfate concentration was further reduced to $213 \mathrm{ppm}$ from 1043 ppm as shown in Eq. (3)

$6 \mathrm{Ca}^{2+}+3 \mathrm{SO}_{4}{ }^{2-}+2 \mathrm{Al}(\mathrm{OH})_{3}+32 \mathrm{H}_{2} \mathrm{O} \longrightarrow 3 \mathrm{CaO}$. 
Table 3. Different active treatment technology

\begin{tabular}{|c|c|c|c|c|c|c|}
\hline $\begin{array}{l}\text { Sl. } \\
\text { No. }\end{array}$ & Methodology & Membrane used & $\begin{array}{l}\text { Experimental } \\
\text { condition }\end{array}$ & $\begin{array}{l}\text { Percentage } \\
\text { removal }\end{array}$ & Remarks & Reference \\
\hline 1. & $\begin{array}{l}\text { Reverse } \\
\text { Osmosis }\end{array}$ & $\begin{array}{c}\text { Cellulose acetate } \\
\text { membrane }\end{array}$ & $\begin{array}{c}\text { Product rate } 26.2 \\
\mathrm{~g} / \mathrm{hr} \\
\text { Operating } \\
\text { pressure } 300 \mathrm{psig}\end{array}$ & $\begin{array}{l}\text { 95-99\% metal } \\
\text { separation } \\
\text { efficiency }\end{array}$ & $\begin{array}{l}\text { Further reverse } \\
\text { osmosis required } \\
\text { for treated water }\end{array}$ & Sastri, 1979 \\
\hline 2. & $\begin{array}{l}\text { Reverse } \\
\text { Osmosis }\end{array}$ & $\begin{array}{l}\text { Polyamide Ultra- } \\
\text { low-pressure } \\
\text { reverse osmosis }\end{array}$ & $\begin{array}{c}\text { Feed rate at } 1200 \\
\mathrm{~L} / \mathrm{hr} \\
0.9-1.0 \mathrm{Mpa}\end{array}$ & $\begin{array}{c}\text { Removal } \\
\text { percentage of } \mathrm{Ni}^{2+} \\
\mathrm{Cu}^{2+}, \mathrm{Zn}^{2+} \text { and } \mathrm{Pb}^{2+} \\
\text { was } 97.41 \% \text {, } \\
97.73 \%, 97.89 \% \text { and } \\
98.06 \% \text { respectively }\end{array}$ & $\begin{array}{l}\text { No pre and post } \\
\text { treatment } \\
\text { required. } \\
\text { However, higher } \\
\text { pressure required } \\
\text { to enhance the } \\
\text { water recovery, } \\
\text { that give } \\
\text { additional } \\
\text { treatment cost }\end{array}$ & $\begin{array}{l}\text { Zhong et al., } \\
2007\end{array}$ \\
\hline 3. & Filtration & $\begin{array}{l}\text { Nanofiltration } \\
\text { membrane }\end{array}$ & $\begin{array}{c}\text { Feed rate at } 1200 \\
\mathrm{~L} / \mathrm{hr} \\
0.9-1.0 \mathrm{Mpa}\end{array}$ & $\begin{array}{c}\text { Removal } \\
\text { percentage of } \mathrm{Ni}^{2+}, \\
\mathrm{Cu}^{2+}, \mathrm{Zn}^{2+} \text { and } \mathrm{Pb}^{2+} \\
\text { was } 92.45 \% \text {, } \\
93.24 \%, 94.37 \% \text { and } \\
95.19 \% \text { respectively }\end{array}$ & $\begin{array}{l}\text { No pre and post } \\
\text { treatment } \\
\text { required. } \\
\text { However, higher } \\
\text { pressure required } \\
\text { to enhance the } \\
\text { water recovery, } \\
\text { that give } \\
\text { additional } \\
\text { treatment cost }\end{array}$ & $\begin{array}{c}\text { Zhong et al., } \\
2007\end{array}$ \\
\hline 4. & Ion Exchange & - & $\begin{array}{l}\text { Gel type strong } \\
\text { acidic cation } \\
\text { exchange resin of } \\
\text { the sulphonated } \\
\text { polystyrene, } \\
\text { porous medium } \\
\text { base anion } \\
\text { exchange resin } \\
\text { with an acrylic } \\
\text { matrix }\end{array}$ & $\begin{array}{c}100 \% \text { Metal } \\
\text { removal and } 98 \% \text { of } \\
\text { water recovery }\end{array}$ & $\begin{array}{l}\text { different pre- } \\
\text { treatment stages } \\
\text { required, such as } \\
\text { oxidation, } \\
\text { neutralization } \\
\text { and precipitation } \\
\text { with lime and } \\
\text { combination with } \\
\text { different pre- } \\
\text { treatment stages } \\
\text { required, such as } \\
\text { oxidation, } \\
\text { neutralization } \\
\text { and precipitation } \\
\text { with lime and } \\
\text { combination with }\end{array}$ & Feng et al., 2000 \\
\hline 6. & Electrodialysis & $\begin{array}{l}\text { HDX } 200 \text { anion- } \\
\text { exchange and } \\
\text { cation exchange } \\
\text { membrane }\end{array}$ & - & $\begin{array}{c}\text { Metal removal } \\
\text { efficiency was } 97 \%\end{array}$ & $\begin{array}{l}\text { Requires pre- } \\
\text { treatment such } \\
\text { as microfiltration. } \\
\text { Cannot able to } \\
\text { treat AMD with } \\
\text { higher Fe } \\
\text { concentration }\end{array}$ & $\begin{array}{l}\text { Buzzi et al., } \\
\quad 2013\end{array}$ \\
\hline 7. & Natural Zeolites & - & $\begin{array}{c}6 \mathrm{hrs} \text { of reaction } \\
\text { time with dose of } \\
37 \mathrm{~g} / \mathrm{L} .\end{array}$ & $\begin{array}{c}\text { Removal efficiency } \\
\text { of } \mathrm{Fe}^{3+}, \mathrm{Mn}^{2+}, \mathrm{Zn}^{2+} \text {, } \\
\text { and } \mathrm{Cu}-\text { was } 80 \% \text {, } \\
95 \%, 90 \% \text {, and } 99 \% \\
\text { respectively. }\end{array}$ & $\begin{array}{c}\text { Adsorption of } \\
\text { elements } \\
\text { decreases if initial } \\
\text { pH of the AMD } \\
\text { solution is lower. }\end{array}$ & $\begin{array}{l}\text { Motsi et al., } \\
2009\end{array}$ \\
\hline
\end{tabular}


Mg concentration decreased below detection limit when the $\mathrm{pH}$ was increased to 12.25 because of the formation of $\mathrm{Mg}(\mathrm{OH})_{2}$. Treatment of mine water with FA also reduced $\mathrm{Mn}$ concentration below detection limit as $\mathrm{Mn}$ precipitates in the form of $\mathrm{Mn}(\mathrm{OH})_{2}$ at $\mathrm{pH}$ 8.5-9.5 (Madzivire et al., 2014). Along with various heavy metals, sometimes $A M D$ contains different radioactive materials such as uranium (U) and thorium (Th) from the associated bedrock (Madzivire et al., 2014). FA interacted with $U$ and Th present in the water and form $\mathrm{UO}_{2}$ at $\mathrm{ph} \geq 3$ and $\mathrm{ThO}_{2}$ at $\mathrm{pH}>5$. Formation of these compounds helps to remove more than $90 \%$ of $U$ and Th from the water. This in turn reduces the alpha and beta radioactivity by $88 \%$ and $75 \%$ respectively. FA behaves like a sink for these radioactive materials. It was also reported that treatment of $A M D$ with $\mathrm{FA}$, can remove $90 \%$ of $\mathrm{Ra}$ and $\mathrm{Pb}$. Hence, it can be used as a safe adsorbent to treat contaminated gold mine water as no leaching of radioactive materials from coal fly ash to acidic water was reported (Madzivire et al., 2014).

\subsubsection{Modified fly ash}

Although raw coal fly ash is an alternative for the chemical treatment of acid mine drainage, but sometime it shows insufficient adsorption capacity, and poor $\mathrm{pH}$ enhancing capability. Presence of higher amounts of $\mathrm{Al}$ and $\mathrm{Si}$ reduces the efficiency of fly ash. Therefore, to enhance the efficiency, coal fly ash is often modified by soaking in acid or alkaline solution. This chemically modified coal fly ash (MFA) results with greater surface area, lower amounts of $\mathrm{Al}$ and $\mathrm{Si}$, higher $\mathrm{pH}$ value, enhanced pore volume, more loss of ignition and higher percentage metal removal efficiency (Sahoo et al., 2013; Jianping and Haitao 2014; Hsu et al., 2008). $120 \mathrm{~g} / \mathrm{L}$ and $180 \mathrm{~min}$ was optimized as dose and reaction time, respectively, for AMD neutralization by MFA (Sahoo et al., 2013). Table 4 presents the metal removal percentage by MFA. It also enhances the removal efficiency of heavy metal ions like $\mathrm{Cd}^{2+}, \mathrm{Cu}^{2+}, \mathrm{Zn}^{2+}$ due to higher specific surface area and small pore diameter (Jianping and Haito, 2014). Figure 3 depicted the reaction chemistry behind the metal removal by fly ash/modified fly ash. It shows that metal removal is due to adsorption of some metals such as $\mathrm{Cu}, \mathrm{Pb}, \mathrm{Ni}, \mathrm{Zn}$, $\mathrm{Cd}, \mathrm{Mn}$ on the surface of adsorbent. Hydrolysis and precipitation of several metals in the form of $\mathrm{CaSO}_{4}$, $\mathrm{CuSO}_{4}, \mathrm{Cr}(\mathrm{OH})_{3}, \mathrm{Fe}(\mathrm{OH})_{3}, \mathrm{Mn}(\mathrm{OH})_{2}, \mathrm{Al}(\mathrm{OH})_{3}$ and coprecipitation of some metals in the form of $\mathrm{Fe}(\mathrm{OH})_{3}, \mathrm{Cu}^{2+}$, $\mathrm{Al}(\mathrm{OH})_{3}, \mathrm{Zn}^{2+}, \mathrm{Mn}^{2+}$ also play a major role for the metal removal process. Adsorption of metals $\left(\mathrm{Cu}^{2+}\right.$ and $\left.\mathrm{Zn}^{2+}\right)$ and anion such as $\mathrm{SO}_{4}{ }^{2-}$ on the surface of secondary precipitated phases such as ferric hydroxide and aluminium hydroxide is the another major pathway for metal uptake by fly ash/MFA. However, removal efficiency gradually weakened with prolonged reaction time.

\subsubsection{Fly ash synthesized zeolites}

Zeolites can be produced from coal fly ash (CFA) by hydrothermal methods (Nascimento et al., 2009). CFA contains huge amount of silica ( $\mathrm{Si}$ ) and aluminium (Al), which makes it suitable material for formation of zeolites.
Moreover, solid residue generated after treatment of AMD with fly ash can also be converted into synthetic zeolites. It has wide application such as alkylation, isomerization, catalysis for hydrogenation and acts as an excellent adsorbents for the removal of contaminants (heavy metals, toxic gas, organic pollutants such as benzene and alcohol) (Apiratikul and Pavasant, 2008). Synthetic zeolites from CFA shows adsorption capacity 225 times higher than the original CFA (Nascimento et al., 2009) and 3-5 times greater than natural zeolites (Lee et al., 2000), along with $100 \%$ removal of heavy metals (Koukouzas et al., 2010). Ríos et al. (2008) studied the removal of heavy metals from $A M D$ by different adsorbents such as coal fly ash (CFA), natural clinker (NC) and synthetic zeolites such as Natural Clinker Based Faujazite (NCF), Natural clinker-based Na-phillipsite (NCZ), Coal fly ash faujasite (CFAF) made from natural clinker, coal fly ash. NCF enhanced the pH to maximum 9.43 due to the presence of free $\mathrm{CaO}$ inside the faujasite network (Ríos et al., 2008). The order of the adsorbents with respect to $\mathrm{pH}$ enhancement capability followed the trend $\mathrm{NCF}>\mathrm{CFAF}>\mathrm{CFA}>\mathrm{NCZ}>\mathrm{NC}$. Besides the $\mathrm{pH}$ enhancing capability, NCF and CFAF also showed higher metal removal efficiency because of lower $\mathrm{SiO}_{2} / \mathrm{Al}_{2} \mathrm{O}_{3}$ content that brings more terminal $\mathrm{Al}-\mathrm{OH}$ species at zeolite-water interface during entire reaction. The enhancement in the hydrophilic nature of zeolite increases the metal exchange capacity. The principal mechanism associated with metal removal by the adsorbent is precipitation. With increasing $\mathrm{pH}$, metal concentration decreases, which reveals the precipitation of metals on the surface of the sorbents (Ríos et al., 2008).

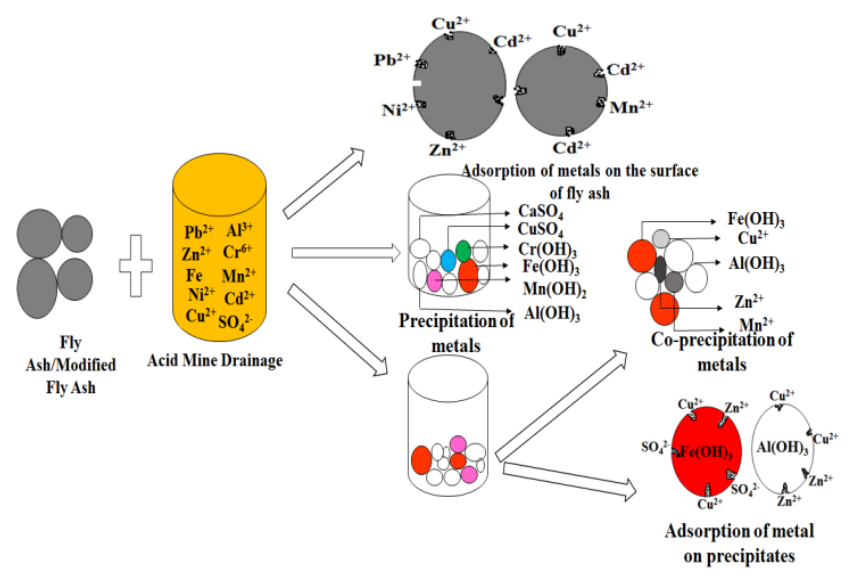

Figure 3. Removal of heavy metals by fly ash/modified fly ash

Extensive literature review demarcates that fly ash, natural zeolites and zeolites synthesis from fly ash has potential to decontaminate the AMD. However, disposal of this fly ash-solid residue after treatment is a matter of concern, as it contains heavy metals on its surface that has environmental impacts like water pollution, soil pollution, etc. Therefore, safe disposal of the solid residue is necessary. Zeolites synthesized from the solid residue, recovered after the treatment of fly ash and AMD, is reported as a very effective adsorbent for the treatment 
of AMD (Petrik et al., 2003; Gitari et al., 2005; Somerset et al., 2008; Vadapalli et al., 2010). Gitari et al. (2005) synthesized ion-exchange adsorbents, in form of zeolites, through high temperature hydrothermal reaction from this solid residue. It was used for comparative analysis for the removal of $\mathrm{Ni}, \mathrm{Zn}$ and $\mathrm{Pb}$ with commercial zeolite. Although removal of $\mathrm{Zn}$ was not significant, however $\mathrm{Ni}$ and $\mathrm{Pb}$ removal efficiency with the synthesized adsorbent was higher than the commercial zeolites. Somerset et al. (2008) studied removal efficiency of zeolite synthesis from fly ash and solid residue. It was found that zeolite produced from solid residue has the ability to remove lead and mercury from acidic wastewater with removal percentage of $95 \%$ and $30 \%$, respectively. While, zeolites synthesized from raw fly ash removed lead up to $88 \%$, but was unable to reduce the mercury concentration. Vadapalli et al. (2010) also investigated about the reuse of the solid residue synthesized product, zeolite-P for the treatment of $\mathrm{CMW}$ up to four number of treatment cycle. The product had a high cation exchange capacity (178.7 meq/100 g) and surface area $\left(69.1 \mathrm{~m}^{2} / \mathrm{g}\right)$. Percentage removal efficiency of zeolite-P presented in Table 4. Metals such as $\mathrm{K}, \mathrm{Ca}, \mathrm{Sr}$, and Ba were efficiently removed by zeolite-P in the first phase of treatment. However, removal of $\mathrm{Mg}$ was insignificant. Although, it was able to remove heavy metals successfully for the first treatment cycle, but removal efficiency exhausted and the $\mathrm{pH}$ decreased from 8.3 to 7.5 with subsequent and rapid treatments, which may be attributed to the competition and adsorption of the other materials on the surface of zeolite. Sodium (Na) was the most important exchangeable cation presented in the zeolite-P product as there was continuous release of $\mathrm{Na}$ found during the experiments. Therefore, solid residue could be effective in the form of synthetic zeolites for the treatment of acidic waste water laden with high concentration of heavy metals.

\subsubsection{Slag}

Slag is considered as waste product from steel making industry. Iron ore or scrap metals are added in molten form with limestone, dolomite or lime in different combination during steel making process. All these calcium components combine with aluminium, silicon, and phosphorous to form slag. Matrix of slag solubilize to release calcium and magnesium oxides which in turn enhance the $\mathrm{pH}$ of dissolving fluid up to 10-11 and help the metals to precipitate in the slag leach bed when AMD passes through it. The neutralization potential (NP) of steel slag is in the range of 45 to $78 \%$. For in-situ AMD treatment, the effluent from the leach beds can infiltrate directly into a spoil or refuse-pile (Ziemkiewicz and Skousen, 1998). Feng et al. (2004) conducted a study using metallurgical by product, slag (Iron slag and Steel slag) for the treatment of gold mine AMD which was highly acidic (pH 2.03) and contained high concentration of different heavy metals. Iron slag, showed much higher adsorption capacity with greater increase in $\mathrm{pH}$ in comparison with steel slag. Optimum $\mathrm{pH}$ value for the metal sorption was 3.5-8.5 for steel slags and 5.2-8.5 for iron slag. Metal adsorption increased as soon as the $\mathrm{pH}$ of iron slag increased (>4.8), due to the enhancement of negative charge on the surface of slag which increases the metal removal by adsorption, precipitation and co-precipitation represented in Figure 4. It illustrates that adsorption of some metals such as $\mathrm{Cu}^{2+}, \mathrm{Cd}^{2+}, \mathrm{Ni}^{2+}, \mathrm{Zn}^{2+}$; precipitation of several metals in their hydroxide form $\left(\mathrm{CaSO}_{4}, \mathrm{CuSO}_{4}\right.$, $\left.\mathrm{Cr}(\mathrm{OH})_{3}, \mathrm{Fe}(\mathrm{OH})_{3}, \mathrm{Mn}(\mathrm{OH})_{2}, \mathrm{Al}(\mathrm{OH})_{3}\right)$ as well as the coprecipitation of some metals in form of $\mathrm{Fe}(\mathrm{OH})_{3}, \mathrm{Cu}^{2+}$, $\mathrm{Al}(\mathrm{OH})_{3}, \mathrm{Zn}^{2+}$ and $\mathrm{Mn}^{2+}$ are the significant metal removal processes from AMD. Moreover, the adsorption of metals $\left(\mathrm{Cu}^{2+}, \mathrm{Zn}^{2+}\right)$ and anion such as $\mathrm{SO}_{4}{ }^{2-}$ on the surface of secondary precipitated phases such as ferric hydroxide and aluminium hydroxide is one of the reason for metal removal as well. In case of steel slag similar phenomenon occurs at ph >3.2. Name and Sheridan (2014) investigated the efficiency of two type of slag, Basic Oxygen Furnace slag (BOF) and Stainless Steel (SS) slag for the treatment of AMD. Metal removal efficiency for different metals are listed in Table $4.30 \mathrm{~g} / \mathrm{L}$ of slag dose and $24 \mathrm{hrs}$ of reaction time was optimum to enhance the $\mathrm{pH}$ to 6.68 and 6.32 for iron slag and steel slag, respectively, with greater sulfate removal in iron slag (Feng et al., 2004). $100 \mathrm{~g} / \mathrm{L}$ dose of BOF slag not only enhances the $\mathrm{pH}$ to a greater value in comparison with SS slag, but also results in higher sulfate removal (Name and Sheridan, 2014). From the comparative study, it was evident that as the dose of steel slag or BOF slag was enhanced percentage reduction of sulfate decreased (Table 4). So, the variation in $\mathrm{pH}$ enhancement and sulfate reduction was attributed to the characteristics of slags used for the treatment. Calcium content was more in case of iron slag $(46.3 \%)$ than steel slag (37.5-38.7\%) and SS slag (36\%). Because of higher calcium content in iron slag higher reduction in sulfate was was observed due to precipitation as gypsum (Gitari et al., 2008). Metal removal efficiency of iron slag was more than BOF slag because of its higher surface area $31.929 \mathrm{~m}^{2} / \mathrm{g}$ than BOF slag $22.333 \mathrm{~m}^{2} / \mathrm{g}$ (Feng et al., 2004). Therefore, the sequence of the adsorbents with respect to metal removal was iron slag>BOF slag> SS slag. Although, the experimental results of batch experiments for the treatment of AMD with slags were very impressive, but AMD treatments in slag leach beds sometimes proves ineffective for prolonged period of reaction time. This might be due to limitation of dissolvable calcium compounds on the surface of slag particles that lead to low alkalinity loadings. Accumulation of thick layer of precipitation in the effluent piping as well as formation of precipitates within slag resulted in lower alkalinity values (Goetz and Riefler, 2014).

\subsubsection{Zero valent iron particles}

Zero valent iron $\left(\mathrm{Fe}^{0}\right)$ is one of the common reducing agent, used for the removal of contaminants from wastewater. It behaves as a strong reducing agent as well as it is cost effective and readily available material to reduce the sulfate and enhance the metal precipitation of highly stabilized metal sulfides. Even the corrosion of iron 
promotes the generation of $\mathrm{Fe}^{2+}$ ions that in turn sequester excess sulfide and the effluent contains minimum concentration of toxic metals. It can neutralize the acidity of AMD by generating alkalinity (Eq. (4)) through the corrosion of ZVI (Ayala-Parra et al., 2016).

$\mathrm{Fe}^{0}+2 \mathrm{H}_{2} \mathrm{O} \longrightarrow \mathrm{Fe}^{2+}+\mathrm{H}_{2}+2 \mathrm{OH}^{-}$

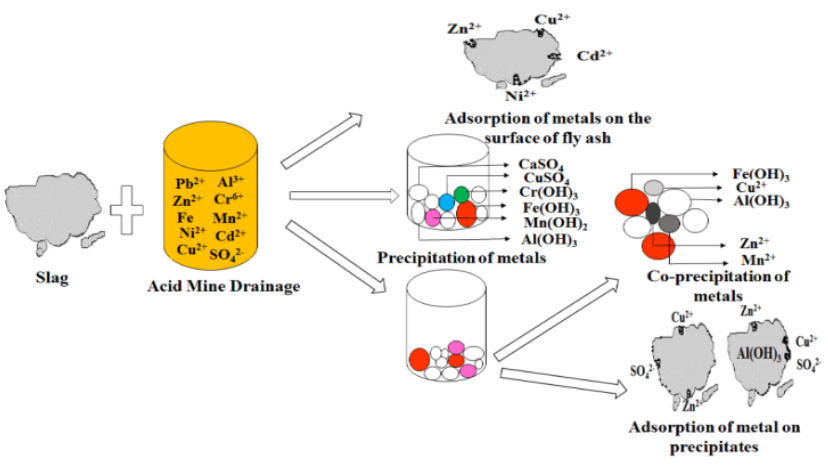

Figure 4. Removal of heavy metals by Slag

Table 4. Removal percentage of metals with different waste material

\begin{tabular}{|c|c|c|c|c|c|c|c|}
\hline $\begin{array}{l}\text { SI } \\
\text { no }\end{array}$ & $\begin{array}{c}\text { Used } \\
\text { material }\end{array}$ & $\begin{array}{l}\text { Optimum } \\
\text { Mixing } \\
\text { ratio/ Dose }\end{array}$ & Initial pH & $\begin{array}{l}\text { Final } \\
\text { pH }\end{array}$ & $\begin{array}{l}\text { Reaction } \\
\text { Time }\end{array}$ & Percentage removal of metals & References \\
\hline 1. & Fly Ash & $1: 3$ & 2.78 & 9.1 & $\begin{array}{l}1440 \\
\text { mins }\end{array}$ & $\begin{array}{l}\text { Greater than } 90 \% \text { for toxic metals, } 78 \% \\
\text { for sulfate }\end{array}$ & $\begin{array}{l}\text { Gitari et al., } \\
\quad 2008\end{array}$ \\
\hline 2. & $\begin{array}{l}\text { Coal Fly } \\
\text { Ash }\end{array}$ & - & 4 & 7.0 & $12 \mathrm{hrs}$. & $\begin{array}{c}60.4 \% \text { sulfate, } 53.4 \% \text { Chemical Oxygen } \\
\text { Demand }\end{array}$ & $\begin{array}{l}\text { Jianping and } \\
\text { Haitao, } 2014\end{array}$ \\
\hline 3. & Fly Ash & - & 2.88 & 12.0 & - & $\begin{array}{c}\text { Removal of } 97.0 \% \mathrm{Al}, 99.9 \% \mathrm{Fe}, 99.98 \% \\
\mathrm{Mn} \text { and } 96.42 \% \mathrm{Zn}\end{array}$ & $\begin{array}{l}\text { Reynolds, } \\
2004\end{array}$ \\
\hline 4. & $\begin{array}{c}\text { FA } \\
\text { followed } \\
\text { by } \\
\text { seeding } \\
\text { with } \\
\text { gypsum } \\
\text { crystals } \\
\text { and the } \\
\text { addition } \\
\text { of } \\
\text { amorpho } \\
\text { us } \\
\mathrm{Al}(\mathrm{OH})_{3}\end{array}$ & $1: 2$ & $6.6 \pm 0.21$ & 12.25 & - & Removal of $79.57 \%$ sulfate & $\begin{array}{l}\text { Madzivire et } \\
\text { al., } 2010\end{array}$ \\
\hline 5. & $\begin{array}{l}\text { Alkaline } \\
\text { Ash } \\
\text { Leachate } \\
\text { s }\end{array}$ & - & $3.3-5.0$ & 8.0 & 7 days & $\begin{array}{l}\text { Removal of } 99.97 \% \text { of } \mathrm{Cu}, 99.78 \% \text { of } \mathrm{Zn} \text {, } \\
90.2 \% \text { of } \mathrm{Cd}, 99.94 \% \text { of } \mathrm{Pb}, 62.71 \% \text { of } \mathrm{Ni} \\
\text { and } 99.41 \% \text { of } \mathrm{Co} \text {. }\end{array}$ & $\begin{array}{l}\text { Bäckström } \\
\text { and Sartz, } \\
2011\end{array}$ \\
\hline 6. & $\begin{array}{l}\text { Modified } \\
\text { Fly Ash }\end{array}$ & $120 \mathrm{~g} / \mathrm{L}$ & 1.6 & $2.8-6.6$ & $180 \mathrm{~min}$ & $\begin{array}{c}89 \%, 92 \%, 94 \%, 96 \%, 60 \% \text {, and } 99 \% \text { for } \\
\mathrm{Ni}, \mathrm{Zn}, \mathrm{Pb}, \mathrm{Fe}, \mathrm{Mn} \text {, and } \mathrm{Al} \text { respectively }\end{array}$ & $\begin{array}{l}\text { Sahoo et al., } \\
2013\end{array}$ \\
\hline 7. & $\begin{array}{l}\text { Modified } \\
\text { Fly Ash }\end{array}$ & - & 4 & & $\begin{array}{c}36-120 \\
\text { hrs }\end{array}$ & $82.4 \%$ of $\mathrm{Cd}^{2+}, 91.85 \%$ of $\mathrm{Cu}^{2+}, 57.2 \% \mathrm{Zn}^{2+}$ & $\begin{array}{l}\text { Jianping and } \\
\text { Haitao, } 2014\end{array}$ \\
\hline 8. & $\begin{array}{l}\text { Natural } \\
\text { Clinker- } \\
\text { Based } \\
\text { Faujasite }\end{array}$ & $\begin{array}{l}0.25 \mathrm{gm} \\
\text { and } 1 \mathrm{gm} \text { in } \\
20 \mathrm{ml}\end{array}$ & 1.96 & $\begin{array}{l}4.29- \\
9.43\end{array}$ & $24 \mathrm{hrs}$ & $\begin{array}{l}\text { Approximately complete removal of } \mathrm{Fe}, \mathrm{As} \\
\text { and ammonium. Partial removal of } \mathrm{Cu} \text { and } \\
\mathrm{Zn} \text {. }\end{array}$ & $\begin{array}{l}\text { Ríos et al., } \\
2008\end{array}$ \\
\hline 9. & $\begin{array}{l}\text { Synthetic } \\
\text { Zeolite }\end{array}$ & $20 \mathrm{~g} / \mathrm{L}$ & 2.64 & $\begin{array}{l}4.25- \\
4.88\end{array}$ & $1 \mathrm{hr}$ & Removal efficiency for lead is $88 \%$ & $\begin{array}{c}\text { Somerset et } \\
\text { al., } 2008\end{array}$ \\
\hline 10. & $\begin{array}{l}\text { Synthetic } \\
\text { zeolites } \\
\text { (Zeolite- } \\
\text { P) }\end{array}$ & $1 \mathrm{~g} / 100 \mathrm{ml}$ & 6.2 & 8.3 & $1 \mathrm{hr}$ & $\begin{array}{c}\text { Removal of } \mathrm{Al}, \mathrm{Fe}, \mathrm{Mn}, \mathrm{Zn}, \mathrm{Cu}, \mathrm{Ni}, \mathrm{Mg} \text { as } \\
(68 \%-77 \%),(99.1 \%-99.9 \%)(8 \%-64 \%) \\
(58 \%-69.2 \%),(54 \%-88.9 \%),(43 \%-68.6 \%), \\
\text { and (7\%-13\%) respectively }\end{array}$ & $\begin{array}{l}\text { Vadapalli et } \\
\text { al., } 2010\end{array}$ \\
\hline 11. & $\begin{array}{l}\text { Basic } \\
\text { Oxygen } \\
\text { Furnace }\end{array}$ & $30 \mathrm{~g} / \mathrm{L}$ & 2.03 & 6.32 & $24 \mathrm{hrs}$ & $\begin{array}{l}\text { Greater than } 90 \% \text { removal of heavy } \\
\text { metals and anions }\end{array}$ & $\begin{array}{l}\text { Feng et al., } \\
2004\end{array}$ \\
\hline
\end{tabular}




\begin{tabular}{|c|c|c|c|c|c|c|c|}
\hline & $\begin{array}{l}\text { Slag/Ste } \\
\text { el Slag }\end{array}$ & & & & & & \\
\hline 12. & Iron Slag & $30 \mathrm{~g} / \mathrm{L}$ & 2.03 & 6.68 & $24 \mathrm{hrs}$ & $\begin{array}{l}\text { Greater than } 90 \% \text { removal of heavy } \\
\text { metals and anions }\end{array}$ & $\begin{array}{l}\text { Feng et al., } \\
\quad 2004\end{array}$ \\
\hline 13. & $\begin{array}{l}\text { Stainless } \\
\text { Steel } \\
\text { slag }\end{array}$ & $100 \mathrm{gm} / \mathrm{L}$ & 2.5 & 5.9 & 240 mins & Removal of $63.6 \%$ iron, $39.8 \%$ sulfate & $\begin{array}{l}\text { Name and } \\
\text { Sheridan, } \\
2014 \\
\end{array}$ \\
\hline 14. & $\begin{array}{c}\text { Basic } \\
\text { Oxygen } \\
\text { Furnace } \\
\text { Slag/Ste } \\
\text { el Slag }\end{array}$ & $100 \mathrm{gm} / \mathrm{L}$ & 2.5 & 11.3 & 240 mins & Removal of $99.7 \%$ iron, $75 \%$ sulfate & $\begin{array}{l}\text { Name and } \\
\text { Sheridan, } \\
2014\end{array}$ \\
\hline 15. & $\begin{array}{l}\text { Colloidal } \\
\text { Iron }\end{array}$ & $\begin{array}{l}3 \%(w / v) / 1 \\
25 \mathrm{~L}\end{array}$ & 2.3 & 6.5 & $250 \mathrm{hrs}$. & $\begin{array}{c}99.6 \% \text { of } \mathrm{Al}, 64.4 \% \text { of } \mathrm{As}, 97.1 \% \text { of } \mathrm{Cr} \\
98.5 \% \text { of } \mathrm{Zn} \text { and } 19.5 \% \text { of Sulfur }\end{array}$ & $\begin{array}{c}\text { Shokes and } \\
\text { Moller, } 1999\end{array}$ \\
\hline 16. & $\begin{array}{l}\text { Granular } \\
\text { Iron }\end{array}$ & $\begin{array}{l}3 \%(w / v) / 1 \\
25 \mathrm{~L}\end{array}$ & 2.3 & 5 & $250 \mathrm{hrs}$. & $\begin{array}{c}97.7 \% \text { of } A l, 29.6 \% \text { of } A s, 8.2 \% \text { of } \mathrm{Cr}, 3.33 \\
\% \text { of } \mathrm{Zn} \text { and } 4.43 \% \text { of Sulfur }\end{array}$ & $\begin{array}{l}\text { Shokes and } \\
\text { Moller, } 1999\end{array}$ \\
\hline 17. & $\begin{array}{l}\text { Zero } \\
\text { Valent } \\
\text { Iron }\end{array}$ & $0.23 \mathrm{gm} / \mathrm{ml}$ & 2.3 & 5.7 & $24 \mathrm{hrs}$. & $\begin{array}{c}\text { Removal of } 99.90 \% \mathrm{Al}, 97.7 \% \mathrm{Hg}, 99.42 \% \\
\text { As, } 98.4 \% \mathrm{Cd}, 99.98 \% \mathrm{Cu}, 99.78 \% \mathrm{Ni} \text { and } \\
9.81 \% \text { of } \mathrm{Zn}\end{array}$ & $\begin{array}{c}\text { Wilkin and } \\
\text { McNeil, } 2003\end{array}$ \\
\hline 18. & $\begin{array}{c}\text { Zero } \\
\text { Valent } \\
\text { Iron and } \\
\text { mixtures } \\
\text { of } \\
\text { Organic } \\
\text { carbon }\end{array}$ & - & $4.5-4.8$ & $\begin{array}{l}6.38- \\
6.87\end{array}$ & 60 days & $\begin{array}{c}\text { Removal of Fe }(91.6-97.6 \%), \mathrm{Zn}(>99.9 \%) \\
\mathrm{Cd}(>99.9 \%), \mathrm{Ni}(>99.9 \%), \mathrm{Co}(>99.9 \%) \mathrm{Al} \\
(>99.9 \%), \mathrm{Mn}(89.9-90.6 \%) \text { and } \mathrm{Pb}(94.6- \\
96.9 \%)\end{array}$ & $\begin{array}{l}\text { Lindsay et al., } \\
2008\end{array}$ \\
\hline 19. & $\begin{array}{l}\text { Zero } \\
\text { Valent } \\
\text { Iron }\end{array}$ & - & 4.8 & $\begin{array}{l}7.32- \\
7.61\end{array}$ & 60 days & $\begin{array}{l}\text { Removal of } 31.3 \% \mathrm{Fe}, 76.75 \% \mathrm{Co}, 98.2 \% \\
\mathrm{Zn}, 99 \% \mathrm{Ni} \text { and } \mathrm{Cd} \text {, and } \mathrm{Pb}(94.6-96.9 \%)\end{array}$ & $\begin{array}{l}\text { Lindsay et al., } \\
2008\end{array}$ \\
\hline 20. & $\begin{array}{l}\text { Cement } \\
\text { Kiln Dust } \\
\text { Slurry }\end{array}$ & $\begin{array}{l}25 \% \text { of CKD } \\
\text { slurry }\end{array}$ & $(2.4 \pm 0.1)$ & 9.5 & 1 minute & $98 \%$ of zinc and $97 \%$ of iron & $\begin{array}{l}\text { Mackie and } \\
\text { Walsh, } 2012\end{array}$ \\
\hline 21. & $\begin{array}{l}\text { Rice } \\
\text { Husk }\end{array}$ & $1: 10$ & 2.3 & 4.0 & $24 \mathrm{hrs}$. & $99 \% \mathrm{Fe}^{3+}, 98 \% \mathrm{Fe}^{2+}, 98 \% \mathrm{Zn}^{2+}, 95 \% \mathrm{Cu}^{2+}$ & $\begin{array}{l}\text { Chockalingam } \\
\text { and } \\
\text { Subramanian, } \\
2006\end{array}$ \\
\hline 22. & $\begin{array}{l}\text { Peat } \\
\text { Humic } \\
\text { Agent }\end{array}$ & $1: 500$ & 2.7 & 3.1 & $1 \mathrm{hr}$ & $\begin{array}{c}\text { Removal of } 36 \% \mathrm{Fe}, 26 \% \mathrm{Al}, 20 \% \mathrm{Zn}, 35 \% \\
\mathrm{Cu}, 43 \% \mathrm{Cd}, 98 \% \mathrm{~Pb}, 40 \% \mathrm{Ni}, 21 \% \mathrm{Co}\end{array}$ & $\begin{array}{l}\text { Bogush and } \\
\text { Voron, } 2010\end{array}$ \\
\hline 23. & $\begin{array}{l}\text { Peat } \\
\text { Humic } \\
\text { Agent }\end{array}$ & $1: 500$ & 4.1 & 5.3 & $1 \mathrm{hr}$ & $\begin{array}{c}\text { Removal of } 95 \% \mathrm{Fe}, 99 \% \mathrm{Al}, 21 \% \mathrm{Zn}, 23 \% \\
\mathrm{Cu}, 23 \% \mathrm{Cd}, 15 \% \mathrm{Ni} \text { and } 18 \% \mathrm{Co}\end{array}$ & $\begin{array}{l}\text { Bogush and } \\
\text { Voronin, } 2010\end{array}$ \\
\hline 24. & $\begin{array}{l}\text { Peat } \\
\text { Humic } \\
\text { Agent }\end{array}$ & $1: 500$ & 4.8 & 7.1 & $1 \mathrm{hr}$ & $\begin{array}{l}\text { Removal of } 94 \% \mathrm{Fe}, 99.9 \% \mathrm{Al}, 96 \% \mathrm{Zn} \text {, } \\
99 \% \mathrm{Cu}, 76 \% \mathrm{Cd}, 61 \% \mathrm{Ni} \text { and } 57 \% \mathrm{Co} .\end{array}$ & $\begin{array}{l}\text { Bogush and } \\
\text { Voronin, } 2010\end{array}$ \\
\hline
\end{tabular}

Abiotic removal of metals take place by different processes such as adsorption onto the surfaces of $\mathrm{Fe}^{0}$ and precipitation. Iron has proved as an effective material in changing the chemistry of acidic system towards conditions promoting immobilization of dissolved heavy metals, increase in $\mathrm{pH}$, and decrease in redox potential (Shokes and Moller, 1999). Extensive studies were carried out with $\mathrm{Fe}^{0}$ in the form of iron fillings, iron chips and used in batch study as well as in permeable reactive barrier for the removal of different toxic metals such as chromium $(\mathrm{Cr})$, mercury $(\mathrm{Hg})$, nickel $(\mathrm{Ni})$, copper $(\mathrm{Cu})$ and organic compounds from contaminated water (Blowes et al., 1997; Puls et al., 1997; Weisener et al., 2005; Sinha and Bose, 2009; Moraci and Calabrò, 2010). Complete removal of radioactive metal such as uranium was also reported with iron particles (Gu et al., 1998). Shokes and Moller (1999) carried out their study with diversified form of $\mathrm{Fe}^{0}$ such as, colloidal iron and granular iron. Wilkin and McNeil (2003) used granular iron of two different mesh size; peerless iron of $(-8+50)$ mesh particle size and fisher iron of $(-100)$ mesh particle size for their experiment. Both the iron particles showed the enhancement of $\mathrm{pH}$ from 
2.3 to 5.7-6.5. AMD solution with lower initial $\mathrm{pH}$, such as 3.5 and 4.5 reached to higher final $\mathrm{pH}$ of 9.6-10.0 after several hours of reaction (Wilkin and McNeil, 2003). Metal removal efficiency for both the experiments is presented in Table 4. However, metal removal efficiency of colloidal iron is better than granular iron because of their specific surface area. Surface area of colloidal iron was $0.3 \mathrm{~m}^{2} / \mathrm{g}$ whereas $0.005 \mathrm{~m}^{2} / \mathrm{g}$ for granular iron. As the surface area was much less therefore, granular iron does not have adequate surface area to enhance the $\mathrm{pH}$ to 7 or to maintain a reducing environment by generating hydroxyl ions (Shokes and Moller, 1999). Shokes and Moller (1999) reported $\mathrm{Ni}$ removal percentage with colloidal iron and granular iron was $74.5 \%$ and $7.1 \%$, respectively. Whereas, Wilkin and McNeil (2003) reported the removal percentage as $99.78 \%$ with granular iron. Similarly for $\mathrm{Zn}$, removal percentage was observed to be $98.5 \%$ and $3.33 \%$ with colloidal iron and granular iron, respectively (Shokes and Moller, 1999), in comparison to $98.81 \%$ for peerless iron and $99.78 \%$ for fisher iron, respectively (Wilkin and McNeil, 2003). The variation in the results might be due to the specific surface area of both the granular iron. Specific surface area of peerless iron and fisher iron was reported as $3.05 \mathrm{~m}^{2} / \mathrm{g}$ and $0.05 \mathrm{~m}^{2} / \mathrm{g}$ (Wilkin and McNeil, 2003), which is more than reported by Shokes and Moller (1999). However, there was no significant difference in percentage removal for peerless iron and fisher iron. This may be due to the same $\mathrm{pH}$ attained by both granular irons and precipitation of the metals took place according to their own precipitating $\mathrm{pH}$ values. Removal of sulfate by Fisher iron was two times more than the reduction by pearless iron at same dose level. However, Mn removal by ZVI was insignificant (Wilkin and McNeil, 2003). This may be due to release of $\mathrm{Mn}$ ions from $\mathrm{ZVI}$ at low $\mathrm{pH}$ values. $\mathrm{Ni}$ and $\mathrm{Zn}$ removal took place due to the formation of complexes with hydroxide and sulfate. Removal process for antimony $(\mathrm{Sb})$ was very slow and it took several hours to achieve $86 \%$ of removal. It was reported that the oxidation state of As does not changed by ZVI, it remain in As(V) form in the solution (Wilkin and McNeil, 2003). It forms complexes with iron oxide and removed by coprecipitation with sulfides, iron oxides and iron oxyhydroxides. $\mathrm{Cd}$ and $\mathrm{Cu}$ bind on the surface of the iron by reduction into its elemental metal form. Al precipitate as $\mathrm{Al}(\mathrm{OH})_{3}$ (Wilkin and McNeil, 2003; Shokes and Moller, 1999). Figure 5 depicted the removal process of metals by $\mathrm{ZVI}$. Adsorption is considered as the initial and most rapid metal uptake mechanism. $\mathrm{Cu}^{2+}$ and $\mathrm{Cd}^{2+}$ reduced by $\mathrm{ZVI}$ and adsorption of elemental $\mathrm{Cu}$ and $\mathrm{Cd}$ take place on the surface of ZVI itself. Similarly, precipitation of metals according to their hydroxide form such as $\mathrm{Cr}(\mathrm{OH})_{3}$, $\mathrm{Fe}(\mathrm{OH})_{3}, \mathrm{Al}(\mathrm{OH})_{3}, \mathrm{Mn}(\mathrm{OH})_{2}, \mathrm{Ni}(\mathrm{OH})_{2}$ occur. Sulfate may be removed from the solution by precipitation of metal sulfur compounds such as metal sulfate $\left(\mathrm{NiSO}_{4}, \mathrm{CuSO}_{4}\right)$, metal hydroxide compounds $\mathrm{Fe}_{6}(\mathrm{OH})_{12} \mathrm{SO}_{4} \cdot \mathrm{nH}_{2} \mathrm{O}$ or coprecipitate as metal hydroxide $\left(\mathrm{M}_{6}(\mathrm{OH})_{12} \mathrm{SO}_{4}\right)$. Iron corrodes in acidic solution and formed iron oxy hydroxide and iron oxides and co precipitated on the metal surface. $\mathrm{As}^{5+}$ co-precipitated with iron oxide or iron oxy hydroxide or cemented on the surface of ferrihydrite $\left(\mathrm{Fe}_{5} \mathrm{HO}_{8} .4 \mathrm{H}_{2} \mathrm{O}\right)$.
$\mathrm{Ni}^{2+}$ and $\mathrm{Zn}^{2+}$ form complex with hydroxide and sulfate or cemented on the surface of ferrihydrite.

Under anaerobic condition sulfate reduction leads to the corrosion of $\mathrm{Fe}^{0}$ and forms $\mathrm{Fe}$ (II) along with $\mathrm{OH}^{-}$and $\mathrm{H}_{2}$ (Eq. 4). Molecular $\mathrm{H}_{2}$, is utilized by some sulfate reducing bacteria (SRB) species as an electron donor for $\mathrm{SO}_{4}{ }^{2-}$ reduction (Eq.5) (Karri et al., 2005; Ayala-Parra et al., 2016).

$\mathrm{SO}_{4}{ }^{2-}+4 \mathrm{H}_{2}+\mathrm{H}^{+} \longrightarrow \mathrm{HS}^{-}+4 \mathrm{H}_{2} \mathrm{O}$

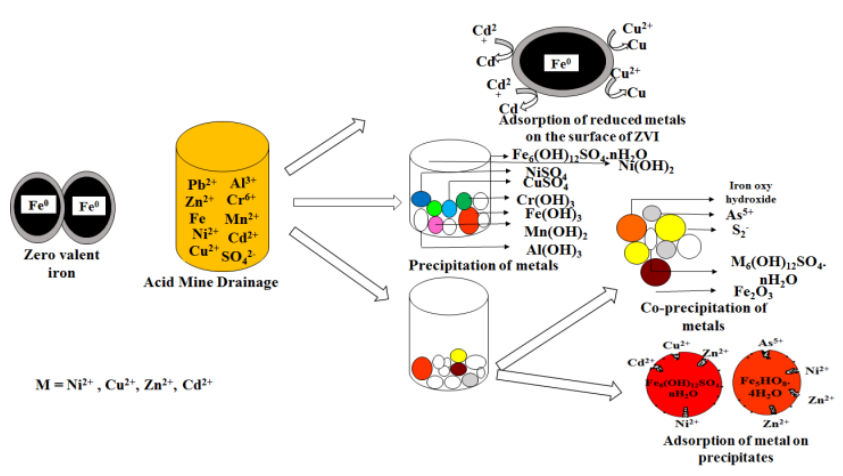

Figure 5. Removal of heavy metals by Zero Valent Iron

Table 5. Composition of reactive mixtures expressed as dry weight percentages (dry wt.\%) (Lindsay et al., 2008)

\begin{tabular}{cccccc}
\hline $\begin{array}{l}\text { Reactive } \\
\text { mixture }\end{array}$ & \multicolumn{5}{c}{ Reactive mixture composition (dry wt. \%) } \\
& & & & & \\
& OC & $\mathbf{F e}^{0}$ & Inoculum & Limestone & $\begin{array}{c}\text { Silica } \\
\text { Sand }\end{array}$ \\
\hline RM1 & 50 & 0 & 2 & 16 & 32 \\
\hline RM2 & 48 & 2 & 2 & 16 & 32 \\
\hline RM3 & 45 & 5 & 2 & 16 & 32 \\
\hline RM4 & 40 & 10 & 2 & 16 & 32 \\
\hline RM5 & 0 & 50 & 2 & 16 & 32 \\
\hline
\end{tabular}

It was reported that some heterotropic bacteria such as Desulfovibrio desulfuricans oxidize $\mathrm{H}_{2}$ but it requires some organic carbon (OC) source for their growth (Ehrlich, 2002). Permeable reactive barrier (PRB) contained mixture of $\mathrm{Fe}^{0}$ and $\mathrm{OC}$ that promotes the growth of SRB, which in turn reduces sulfate with buffering of $\mathrm{pH}$ and enhanced removal of metals/trace elements (Lindsay et al., 2008; Ayala-parra et al., 2016). Enormous studies have been done to find the effectiveness of zero valent iron and combination of zero valent iron along with organic carbon mixtures for the remediation of AMD (Lindsay et al., 2008; Ayala-parra et al., 2016). Compositions of reactive-mixtures (RM) are presented in the Table 5 . Experimental results showed rapid decrease in metal concentration and sharp increase in $\mathrm{pH}$ within 1 day. Although, metal removal under sulfate reducing condition takes place due to metal-sulfide precipitation, but other mechanisms such as (oxy) hydroxide precipitation, coprecipitation and surface complexation also acts as key 
mechanisms for metal removal. Similar sulfate reduction rate (SRR) was observed for RM3 and RM4. Manganese $(\mathrm{Mn})$ concentration eventually increase $(28.3 \%)$ in $\mathrm{RM} 5$, at $\mathrm{ph}<8$ as $\mathrm{Mn}$-hydroxide was not precipitated. From the results it is inferred that except $\mathrm{Fe}$ and $\mathrm{Mn}$, removal efficiency for all heavy metal was almost similar when $\mathrm{Fe}^{0}$ was used either solely or in combination with OC. Ayarapara et al. (2016) reported similar observation, with respect to using limestone (LS) and ZVI for the treatment of AMD. LS aids as buffer as well as inorganic food for lithoptropic SRB that can utilize $\mathrm{CO}_{2}$ as a carbon source. Increasing sulfate reduction observed in ZVI-LS column than ZVI column, where sulfate reduction ceased after small reaction time in LS column. Metal removal efficiency in all the columns was more than $98 \%$. In ZVI column, metal removal took place due to the formation of metal sulfides. It was observed from the solid-phase analyses that heavy metals precipitated with biogenic sulfide in the columns packed with ZVI. However, in absence of ZVI, heavy metals were also significantly removed due to precipitation with hydroxide and carbonate ions released from limestone, though LS surfaces are super saturated after a while. Therefore, in case of permeable reactive barrier (PRB), small amount of $\mathrm{Fe}^{0}$ can make the system efficient and cost effective. ZVI acts as an efficient reducing agent for treatment of $A M D$, specifically for sulfate reduction when associated with PRB system (Ayala-parra et al., 2016).

It is concluded that zero valent iron is effective to decontaminate the acid mine drainage through various reaction mechanism from its soluble toxic metals as well as anions such as sulfate, chloride etc. However, if groundwater is contaminated with sulfate rich ground water then the prime corrosion product of zero valent iron is green rust. Regular adsorption of green rust on the top of the iron corrosion products, co-precipitation with corrosion products or combination of both makes the metal uptake process much slower. Another important factor that also hinders the efficiency of $\mathrm{ZVI}$, is the presence of high concentration of total dissolved solid loads (TDS). Loss of permeability and high rates of mineral precipitation, due to high loads of TDS, also acts as barrier for the efficiency of ZVI (Wilkin and McNeil, 2003).

\subsubsection{Cement klin dust}

Cement Klin Dust (CKD) is known as caustic-material, which is produced during the cement production in cement klin. In cement production, the raw materials such as limestone along with quicklime, eventually converts into lime by removal of carbon dioxide within klin. Pollution control devices such as Bag house filter and electrostatic precipitator (ESP) remove the small particles of CKD, present in the exhaust gases generated from cement kiln. This waste product contains 8-61\% (weight \%) of total $\mathrm{CaO}$ (Mackie and Walsh, 2012). Extensive literature studies reported that CKD is able to remove the pollutant and toxic heavy metals from the wastewater with approximately $100 \%$ removal percentage (El-Awady and Sami, 1997; Zaki et al., 2007). Mackie and Walsh (2012) conducted a bench-scale study to evaluate the efficiency of CKD for acid mine water treatment. Four type of CKD sample (CKD-A, CKD-B, CKD-C, and CKD-F) whose particle sizes were $34-73 \%$ smaller and specific surface areas 2-3 times greater than the quicklime samples were used in this study. Treatment of mine water with $25 \%$ of CKD (w/v) removed $98 \%$ of total zinc and $97 \%$ of total iron concentration. Metal removal percentage are presented in Table 4. Surface adsorption, hydrolysis and precipitation of the heavy metals are the removal mechanism of toxic metals (Figure 6). It illustrates that adsorption as well as the precipitation of metal $(\mathrm{Cu}, \mathrm{Pb}$, $\mathrm{Cd}, \mathrm{Zn})$ as their hydroxide $\left(\mathrm{Cu}(\mathrm{OH})_{2}, \mathrm{Cr}(\mathrm{OH})_{3}, \mathrm{Fe}(\mathrm{OH})_{3}\right.$, $\left.\mathrm{Al}(\mathrm{OH})_{3} \mathrm{~Pb}(\mathrm{OH})_{2}\right)$ and sulfate form $\left(\mathrm{CaSO}_{4}\right)$ are major metal removal path followed by CKD. However, among all the CKD samples, CKD-F has the highest free lime content. Therefore, removal efficiency of CKD-F is slightly better than other CKDs. All CKD samples were able to achieve more than $98 \%$ and $97 \%$ precipitation of soluble $\mathrm{Zn}$ and Fe concentration, respectively. Moreover, CKD-treated samples generated less sludge by volume $(50 \%-60 \%)$ than the sample treated with quicklime slurry. Therefore, CKD is a promising treatment option to reduce acidity, precipitate and remove metals as they generate only 50$60 \%$ of sludge compared to lime. However, increasing settling time or polymer doses might be needed to meet the treatment requirements. Even though the treatment results are significant, but to treat the mine water with CKD, much higher volumes of slurry is required to reach the target $\mathrm{pH}$ of 9 with respect to quicklime slurry.

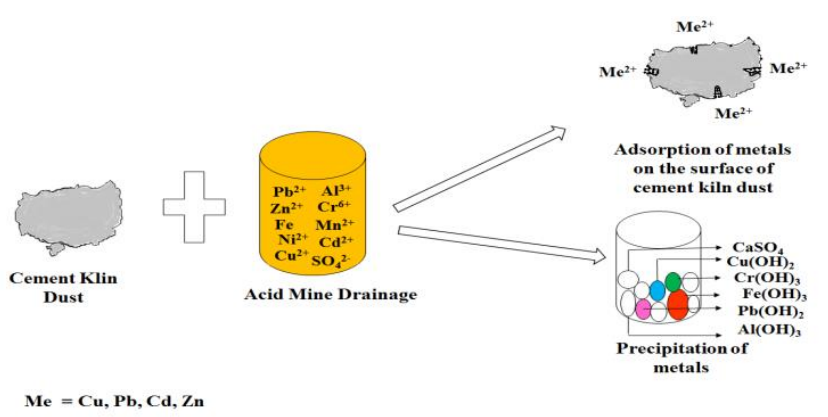

Figure 6. Removal of heavy metals by Cement Klin Dust

\subsubsection{Organic waste material}

Organic substrates such as rice husk and peat humic agent (PHA) are also considered as potent adsorbents for the metal ions. Humic agents are high molecular complex organic compounds formed due to the decomposition of vegetative and animal residue by microorganisms and abiotic factors (Orlov, 1990). Carboxyl group present in humic agent in the form of humic acid ( $\mathrm{Hu}-\mathrm{COOH}$ ) and sodium humate (Hu-COONa) produce humate ion, a hydroxonium ion and a sodium ion via dissociation. This humate ion form humate complex by reacting with metal ions (Eq. (6) and Eq.(7)) (Bogush and Voronin, 2010).

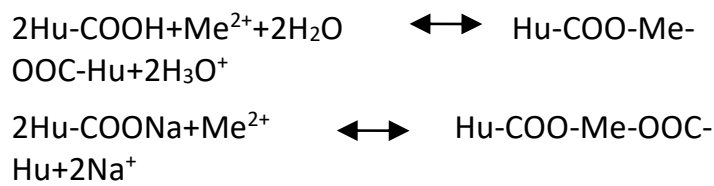

\section{$\mathrm{Hu}+2 \mathrm{Na}^{+}$}


Organic materials and humic agents consist of carboxyl, hydroxyl, carbonyl, amide and phenolic group, attached to larger organic molecules, which in turn bind the metal ions (Bogush et al., 2007). Organic compounds act as an excellent energy source for the SRB. These organic compounds can be utilized as an adsorbent for the removal of heavy metals from wastewater. Chockalingam and Subramaniam (2006) studied the metal ions removal and sulfate reduction using rice husk and SRB (Desulfotomaculum nigrificans) for the remediation of AMD. AMD and simulated AMD with $\mathrm{pH} 2.3$ were pretreated with rice husk $(10 \mathrm{gm} / 100 \mathrm{ml})$ in the study. After pre-treatment, $\mathrm{pH}$ of $\mathrm{AMD}$ and simulated mine water increased to approximately 4.5 and 6.1 respectively. For sulfate reduction tests, acid mine water of $\mathrm{pH} 2.3$ were interacted with 10, 16 and $20 \mathrm{~g}$ of rice husk for 1 hour so that the final $\mathrm{pH}$ values became constant at 4.6, 5 and 5.3 respectively. There was no significant sulfate removal after 24 hours. However, after inoculation of $D$. nigrificans into AMD, sulfate reduction increased to $40 \%$ from $21 \%$ at $\mathrm{pH} 5.3$ after 31 days by using rice husk filtrate in addition with nitrogen and carbon contents. In case of simulated AMD, sulfate removal percentage was observed to be $73 \%$ after 35 days. However, concentration of sulfate again increased after the point of its reduction for both the cases. This might be due to the co-precipitation of sulfate and ferric (oxy) hydroxides in the acid mine water sample and its subsequent dissolution in reducing conditions (Christensen et al., 1996). Metal removal process by rice husk is represented in Figure 7.

The figure 7 clearly depict that adsorption of metals $\left(\mathrm{Cu}^{2+}\right.$, $\left.\mathrm{Pb}^{2+}, \mathrm{Fe}^{2+}, \mathrm{Zn}^{2+}\right)$ and conversion of sulfate to sulfide by SRB is the major metal removal process of rice husk associated with SRB. Moreover, the co-precipitation of metals with iron oxy-hydroxide as well as sulfate is the other metal uptake procedure form AMD contaminated water.

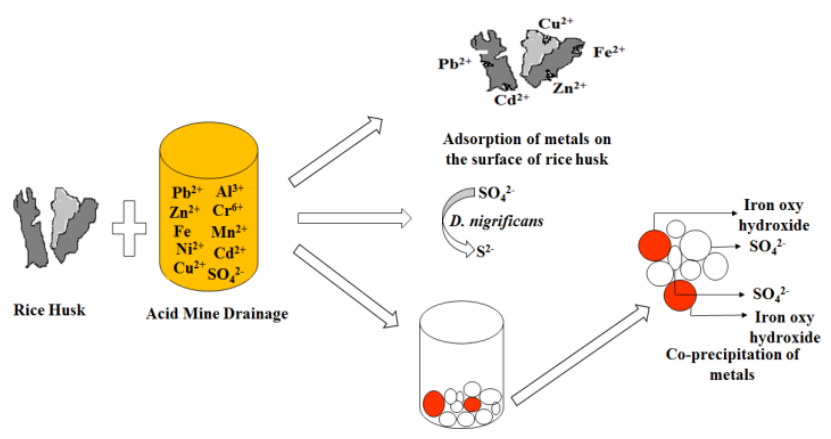

Figure 7. Removal of heavy metals by Rice Husk

Treatment of acid mine drainage with peat humic agent was carried out by Bogush and Voronin (2010). Three PHA/AMD ratios $(1: 100,1: 500$ and $1: 1000)$ and three different type of AMDs with three different initial $\mathrm{pHs}$ $(2.7,4.1$, and 4.8$)$ was used for this study. It was observed that PHA has the ability to remove heavy metals from the mildly acidic AMD and contains moderate metal concentration by hydrolysis, physical adsorption and coprecipitation of metals on the surface of ferric hydroxide, presented in Figure 8. Adsorption of metals $\mathrm{Pb}^{2+}, \mathrm{Cu}^{2+}$,
$\left.\mathrm{Cd}^{2+}, \mathrm{Ni}^{2+}, \mathrm{Zn}^{2+}\right)$ on the surface of $\mathrm{PHA}$ and the precipitation of metals $\left(\mathrm{Cu}(\mathrm{OH})_{2}, \mathrm{Cr}(\mathrm{OH})_{3}, \mathrm{Fe}(\mathrm{OH})_{3}\right.$, $\left.\mathrm{Mn}(\mathrm{OH})_{2}, \mathrm{Al}(\mathrm{OH})_{3}\right)$ in its hydroxide form are the key mechanism for the metal removal from AMD. However, co-precipitation of the metals as well as the adsorption of metals on the metal precipitates such as $\mathrm{Fe}(\mathrm{OH})_{3}$ are also considered for the metal removal process of PHA. Furthermore, AMD with $\mathrm{pH} 4.8$ was treated with PHA at 1:500 ratio, it removed more than $90 \%$ toxic and other metals and $\mathrm{pH}$ was enhanced to 7.1. Therefore, the order of AMD that can be treated with PHA was as follows, AMD with $\mathrm{pH}$ 4.8>AMD with $\mathrm{pH}$ 4.1>AMD with $\mathrm{pH}$ 2.7. Metal removal percentage is presented in Table 4. Although, PHA are very stable in nature, not prone to biodegradation and thermal destruction, however, in comparison with rice husk, it can only treat mildly acidic water. Therefore, PHA is not beneficial for treating the highly acidic AMD.

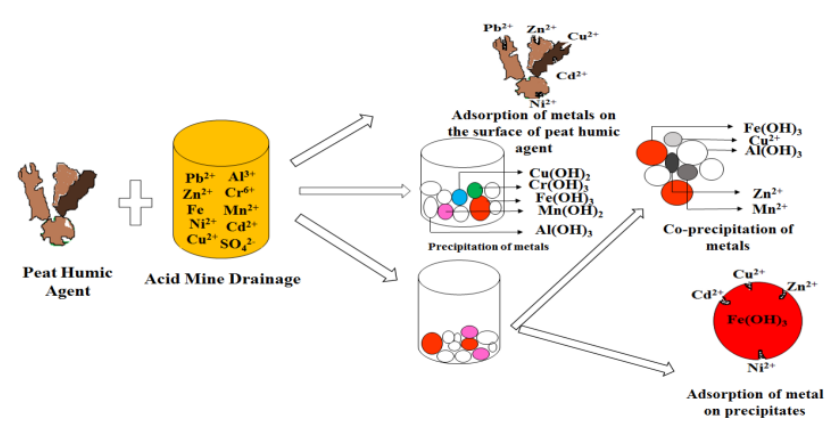

Figure 8. Removal of heavy metals by Rice Husk

\section{Discussion}

\subsection{Enhancement of $\mathrm{pH}$ by different type of waste material}

The prime objective to treat AMD is to increase the level of $\mathrm{pH}$ from acidic to neutral or basic. Researchers have used various waste materials to enhance the $\mathrm{pH}$ of the wastewater.

Fly ash, modified fly ash, metallurgical slag and cement kiln dust have the ability to enhance the $\mathrm{pH}$ of AMD from 2.00 to the range of 8-12 (Gitari et al., 2008; Reynolds, 2004; Bäckström and Sartz, 2011; Ríos et al., 2008; Name and Sheridan, 2014). However, BOF slag has more potential to enhance the $\mathrm{pH}$ from 2.5 to 12.1 than SS slag, which enhance the $\mathrm{pH}$ from 2.5 to 6.6 (Name and Sheridan, 2014). Natural clinker and ZVI are unable to increase the $\mathrm{pH}$ to higher alkaline $\mathrm{pH}$ values. They can enhance the $\mathrm{pH}$ only up to 3.86-5.7 from an initial value of 2.5. Raw fly ash is not able to enhance the $\mathrm{pH}$ of AMD if it contains low lime content. Sahoo et al. (2013) modified the fly ash for the treatment of AMD due to its poor $\mathrm{pH}$ enhancing property. It was reported that fly ash can enhance $\mathrm{pH}$ up to 5.3 without any modification whereas with modification, $\mathrm{pH}$ value can be enhanced to 11.5 . After the conversion of fly ash into zeolites, $\mathrm{pH}$ of the acidic water can be turned into alkaline range i.e. 8.41-12 (Koukouzas et al., 2009; Ríos et al., 2008). However, organic waste such as rice husk and PHA have very low 
capability to enhance the $\mathrm{pH}$. They can enhance the $\mathrm{pH}$ from 2-3 to 3.7-4 (Bogush and Voronin, 2010; Chockalingam and Subramanian, 2006). Lindsay et al. (2008) reported that the treatment of AMD with combination of $\mathrm{ZVI}$ and organic carbon enhances $\mathrm{pH}$ from 4.5 to 7.32 within 11 days. The difference in enhancement of $\mathrm{pH}$ in acidic solution, by different adsorbents, might be due to the variation of calcium and magnesium oxide content available within adsorbents and due to their ability to reduce water and produce hydroxide ions.

\subsection{Effect of dose of adsorbents}

Although all the adsorbents have the ability to decontaminate AMD, but percentage removal for the heavy metals depends on the optimum doses of the adsorbing material. Gitari et al. (2008) carried out the study of AMD treatment with two different ratio of FA:AMD i.e. 1:3 and 1:1.5, respectively. It was evaluated that the maximum percentage removal of heavy metals ( $\mathrm{Mg}, \mathrm{Mn}, \mathrm{Al}, \mathrm{Si}$. Total Fe, $\mathrm{Zn}$ and $\mathrm{Cu}$ ) was at ratio of 1:1.5. Sahoo et al. (2013) evaluated that the maximum removal efficiency of metals with modified fly ash was observed at $120 \mathrm{~g} / \mathrm{L}$ out of $25 \mathrm{~g} / \mathrm{L}, 50 \mathrm{~g} / \mathrm{L}, 80 \mathrm{~g} / \mathrm{L}, 120 \mathrm{~g} / \mathrm{L}$, and $150 \mathrm{~g} / \mathrm{L}$. When the dose of NCF increased from $0.25 \mathrm{~g} / 20 \mathrm{ml}$ to 1 $\mathrm{g} / 20 \mathrm{ml}, \mathrm{pH}$ of the solution enhanced to 9.43 from 1.96 and the metal removal efficiency increased (Koukouzas et al., 2010). Metallurgical slags such as basic oxygen slag and stainless steel slag were tested with different ratios such as 20,40,60, 80, 100, 120 and $140 \mathrm{~g} / \mathrm{L}$ for the treatment of AMD. Finally, it was concluded that for both the material, $100 \mathrm{~g} / \mathrm{L}$ is optimum for maximum removal of metals (Name and Sheridan, 2014). In case of ZVI, Wilkin and McNeil (2003) carried out study with different dose of iron, i.e, $0.02 \mathrm{~g} / \mathrm{ml}$ to $0.23 \mathrm{~g} / \mathrm{ml}$ where maximum percentage removal was observed at $0.23 \mathrm{~g} / \mathrm{ml}$ of iron dose. PHA was used as adsorbent with three different PHA: AMD ratio of $1: 1000,1: 500$ and $1: 100$ and $1: 500$ ratio was the most efficient dose for the treatment of mild acidic AMD (Bogush and Voronin, 2011).

\subsection{Effect of initial $p H$ values of $A M D$}

Acidic effluent can be converted into neutral effluent with the adsorbents. However, initial $\mathrm{pH}$ of the AMD plays an important role in the attainment of alkaline conditions and neutralization of AMD. Wilkin and McNeil (2003) investigated that when the AMD has initial $\mathrm{pH}$ of 2.3, ZVI was able to enhance the $\mathrm{pH}$ up to 5.7-6. However, when the initial pHs of the solution were 3.5 and 4.5, enhancement of the $\mathrm{pH}$ took place up to 9.8-10. At this increased $\mathrm{pH}$, higher percentage of metal removal occurred. Bogush and Voronin (2010) investigated that the AMD with initial $\mathrm{pH}$ 2.7, reached to $\mathrm{pH}$ 2.9-3.1 only with PHA. However, when initial $\mathrm{pH}$ of the effluent was 4.8, PHA enhanced the $\mathrm{pH}$ values to 8.2. Lindsay et al. (2008) showed that, $\mathrm{pH}$ enhanced to 6.38 when the initial $\mathrm{pH}$ of AMD was 4.5 with OC associated with ZVI.

\section{Conclusion}

This paper critically reviewed the application and selection of waste materials for the treatment of AMD. Although, active treatments are effective, but they incur high installation and adsorbent cost. Beside this, some active treatment such as reverse osmosis, ion exchange, electrodialysis need pre-treatment of the influent, which enhances the whole treatment cost. Waste material on other side reduces environmental load and are economically viable alternative for the treatment purpose. After consideration and reviewing different studies, it can be concluded that among all the waste material, fly ash and its derivatives such as modified fly ash and fly ash synthesized zeolites, slag, CKD can be preferred among all the waste material for the treatment of extreme acidic AMD. They have more potential to enhance the $\mathrm{pH}$ of extreme acidic solution as well as removal of pollutants from the solution. On the other side, ZVI and organic waste can be used if the AMD is mild or less acidic in nature. OC along with ZVI and SRB can be considered as potential option if the sulfate concentration in AMD is high. However, specific surface area, $\mathrm{pH}$ enhancing capacity, adsorption capability, retention time, leachability of different metals from adsorbents into the treated water, cost effectiveness, environmental impact must be taken into consideration prior to the selection of the waste material as an adsorbent. This study will be beneficial for the readers to choose suitable and specific waste material for field condition as well as it will facilitate future research requirements for the treatment of AMD.

\section{Acknowledgement}

We acknowledge Ministry of Human Resource Development, Government of India for the financial support. In addition, we would like to thank Department of Environmental Science and Engineering, Indian Institute of Technology (Indian School of Mines) Dhanbad for the logistical support.

\section{References}

Akcil, A., and Koldas, S. (2006), Acid Mine Drainage (AMD): causes, treatment and case studies, Journal of Cleaner Production, 14, 1139-1145.

Ali, M.S. (2011). Remediation of Acid Mine Waters. "Mine WaterManaging the Challenges", In: Proceeding IMWA, pp 253257.

Apiratikul, R., and Pavasant, P. (2008), Sorption of $\mathrm{Cu}^{2+}, \mathrm{Cd}^{2+}$, and $\mathrm{Pb}^{2+}$ using modified zeolite from coal fly ash, Chemical Engineering Journal, 144, 245-258.

Aubé, B., and Eng, P. (2004) The Science of Treating Acid Mine Drainage and Smelter Effluents, Unpubl report, Ste-Anne-deBellevue.

Ayala-Parra, P., Sierra-Alvarez, R., and Field, J.A. (2016), Treatment of acid rock drainage using a sulfate-reducing bioreactor with zero-valent iron. Journal of Hazardous Materials, 308, 97-105.

Bäckström, M., and Sartz, L. (2011), Mixing of Acid Rock Drainage with Alkaline Ash Leachates- Fate and Immobilisation of Trace Elements. Water Air Soil Pollution, 222, 377-389.

Baruah, B.P., Saikia, B.K., Kotoky, P., and Rao, P.G. (2006), Aqueous leaching on high sulfur sub-bituminous coals, in Assam, India. Energy and Fuels, 20, 1550-1555.

Blowes, D.W., Ptacek, C.J., and Jambor, J.L. (1997), In-Situ Remediation of $\mathrm{Cr}(\mathrm{VI})$-Contaminated Groundwater Using 
Permeable Reactive Walls: Laboratory Studies. Environmental Science and Technology, 31, 3348-3357.

Bogush, A.A., Letov, S.V., and Miroshnichenko, L.V. (2007), Distribution and speciation of heavy metals in drainage water and sludge pond of the Belovo zinc plant (Kemerovo region), Geoecology, 5,413-420.

Bogush, A.A., and Voronin, V.G. (2010), Application of a Peathumic Agent for Treatment of Acid Mine Drainage. Water Environment, 30,185-190.

Buzzi, D.C., Viegas, L.S., Rodrigues, S., Bernardes, A.M., and Tenório, J.A.S. (2013), Water recovery from acid mine drainage by electrodialysis, Mineral Engineering, 4, 82-89.

Buzzi, D.C., Viegas, L.S., Silvas, F.P.C., Espinosa, D.C.R., Rodrigues, M.A.S., Bernandes, A.M., Tenório, J.A.S. (2011), The Use of Microfiltartion and Electrodialysis for treatment of Acid Mine Drainage. "Mine water- Managing the Challenges", In: Proceeding IMWA, pp 287-291.

Ceptin, S., and Pehlivan, E. (2007), The use of fly ash as a low cost, environmentally friendly alternative to activated carbon for the removal of heavy metals from aqueous solutions, Colloids and Surfaces. A, Physicochemical and Engineering Aspects, 298, 83-87.

Chockalingam, E., and Subramanian, S. (2006), Studies on removal of metal ions and sulfate reduction using rice husk and Desulfotomaculum nigrificans with reference to remediation of acid mine drainage, Chemosphere, 62, 699708.

Christensen, B., Laake, M., and Lien, T. (1996), Treatment of acid mine water by sulfate reducing bacteria: Results from a bench scale experiment, Water Research, 30, 1617-1624.

Dold, B. (2010), Basic concepts in environmental geochemistry of sulphide mine waste management, in: Kumar, E.S., (Ed.), Waste Management, INTECH, pp. 173-198.

Ehrlich, H.L. (2002). Geomicrobiology, fourth ed. Marcel Dekker, New York.

El-Awady, M.H., and Sami, T.M. (1997), Removal of Heavy Metals by Cement Kiln Dust, The Bulletin of Environmental Contamination and Toxicology, 59, 603-610.

Equeenuddin, Sk. Md., Tripathy, S., Sahoo, P.K., and Panigrahi, M.K. (2010), Hydrogeochemical characteristics of acid mine drainage and water pollution at Makum Coalfield, India, Journal of Geochemical Exploration, 105, 75-82.

Erdem, E., Karapinar, N., and Donat, R. (2004), The removal of heavy metal cations by natural zeolites, Journal of Colloid and Interface Science, 280, 309-314.

Erol, M., Kucukbayrak, S., Ersoy-Mericboyu, A., and Ulubas, T. (2005), Removal of $\mathrm{Cu}^{2+}$ and $\mathrm{Pb}^{2+}$ in aqueous solutions by fly ash. Energy Conversion and Management, 46,1319-31.

Expert Team of the Inter-Ministerial Committee. (2010), Mine Water Management in the Witwatersrand Gold Fields with Special Emphasis on Acid Mine Drainage. Report to the InterMinisterial Committee on Acid Mine Drainage. Pretoria: Department of Water Affairs. https://www.dwa.gov.za/Documents/ ACIDReport.pdf. Accessed 24 March 2016.

Feng, D., Aldrich, C., and Tan, H. (2000), Treatment of acid mine water by use of heavy metal recipitation and ion exchange. Minerals Engineering, 13, 623-642.

Feng, D., van Deventar, J.S.J., and Aldrich, C. (2004), Removal of pollutants from acid mine wastewater using metallurgical byproduct slags, Separation and Purification Technology, 40, 61-67.
Fripp, J., Ziemkiewicz, P.F., and Charkavork, H. (2000), Acid Mine Drainage Treatment (No. ERDC-TN-EMRRP-SR-14). U.S. Army Engineer Waterways Experiment Station Vicksburg MS http://el.erdc.usace.army.mil/elpubs/pdf/sr14.pdf. Accessed 25 Jan 2016.

Gaikwad, R.W., Sapkal, V.S., Sapkal, R.S. (2010), Ion exchange system design for removal of heavy metals from acid mine drainage wastewater, Acta Montanistica Slovaca, 15, 298304.

Gitari, W.M., Petrik, L.F., Etchebers, O., Key, D.L., and Okujeni, C. (2008), Utilization of fly ash for treatment of coal mines wastewater: Solubility controls on major inorganic contaminants, Fuel, 87, 2450-2462.

Gitari, W.M., Somerset, V.S., Petrik, L.F., Key, D., Iwuoha, E., and Okujeni, C. (2005), Treatment of Acid Mine Drainage with Fly Ash: Removal of Major, Minor Elements, $\mathrm{SO}_{4}$ and Utilization of the Solis Residues for the Wastewater Treatment, In: World of Coal Ash (WOCA), Lexington, Kentucky, USA, pp 123.

Goetz, E.R., and Riefler, R.G. (2014), Performance of steel slag leach beds in acid mine drainage treatment, Chemical Engineering Journal, 240, 579-588.

Gu, B., Liang, L., Dickey, M.J., Yin, X., Dai, S. (1998), Reductive Precipitation of Uranium (VI) by Zero-Valent Iron, Environmental Science and Technology, 32, 3366-3373.

Heechan, C., Dalyoung, O., and Kwanho, K. (2005), A study on removal characteristics of heavy metals from aqueous solution by fly ash, Journal of Hazardous Materials, 127, 187-195.

Hsu, Ting-Chu., Yu, Chung-Chin., and Yeh, Chin-Ming. (2008), Adsorption of $\mathrm{Cu}^{2+}$ from water using raw and modified coal fly ashes, Fuel, 87, 1355-1359.

Jianping, X., and Haitao, W. (2014), Study on the treatment of acid mine wastewater by coal fly ash, In: Proceeding of International Conference on Material and Environmental Enginerring. Atlantis press, pp 150-153.

Johnson, D.B., and Hallberg, K.B. (2005), Acid mine drainage remediation options: a review, Science of the Total Environment, 338, 3-14.

Karri, S., Sierra-Alvarez, R., and Field, J.A. (2005), Zero-valent iron as an electron donor for methanogenesis and sulfate reduction in anaerobic sludge, Journal of Biotechnology and Bioengineering, 92, 810-819.

Koukouzas, N., Vasilatos, C., Itskos, G., Mitsis, I., and Moutsatsou, A. (2010), Removal of heavy metals from wastewater using CFB-coal fly ash zeolitic materials, Journal of Hazardous Materials, 173, 581-588.

Lindsay, M.B.J., Ptacek, C.J., Blowes, D.W., and Gould, W.D. (2008), Zero-valent iron and organic carbon mixtures for remediation of acid mine drainage: Batch experiments, Applied Geochemistry, 23, 2214-2225.

Mackie, L.A., and Walsh, M.E. (2012), Bench-scale study of active mine water treatment using cement kiln dust (CKD) as a neutralization agent, Water Research, 46, 327-334.

Madzivire, G., Maleka, P.P., Vadapalli, V.R.K., Gitari, W.M., Lindsay, R., and Petrik, L.F. (2014), Fate of the naturally occurring radioactive materials during treatment of acid mine drainage with coal fly ash and aluminium hydroxide, Journal of Environmental Management, 133, 12-17.

Madzivire, G., Petrik, L.F., Gitari, W.M., Ojumu, T.V., and Balfour, G. (2010), Application of coal fly ash to circumneutral mine 
waters for the removal of sulfates as gypsum and ettringite, Minerals Engineering, 23, 252-257.

Manders, P., Godfrey, L., and Hobbs, P. (2009), Briefing Note: Acid Mine Drainage in South Africa, Pretoria: CSIR. http://www.csir.co.za Accessed 16 February 2016.

McCarthy, T.S. (2011), The impact of acid mine drainage in South Africa, South African Journal of Science, 107, (5/6).

Merkel, B., and Mandy, S. (2011), The New Uranium Mining Boom Challenges and Lessons Learned, Springer Heidelberg Dordrecht, London, New York.

Moraci, N., and Calabrò, P.S. (2010), Heavy metals removal and hydraulic performance in zero-valent iron/pumice permeable reactive barriers, Journal of Environmental Management, 91, 2336-2341.

Motsi, T., Rowson, N.A., and Simmons, M.J.H. (2009), Adsorption of heavy metals from acid mine drainage by natural zeolite, International Journal of Mineral Processing, 92, 42-48.

Naicker, K., Cukrowska, E., and Mccarthy, T.S. (2003), Acid mine drainage from gold mining activities in Johannesburg, South Africa and environs, Environmental Pollution, 122, 29-40.

Name, T., and Sheridan, C. (2014), Remediation of acid mine drainage using metallurgical slags, Minerals Engineering, 64, $15-22$.

Nascimento, M., Soares, P.S.M., and Souza, VPaulo de. (2009), Adsorption of heavy metal cations using coal fly ash modified by hydrothermal method, Fuel, 88, 1714-1719.

Ochieng, G.M., Seanego, E.S., and Nkwonta, O.I. (2010), Impacts of mining on water resources in South Africa: A review, Scientific Research and Essays, 5:3351-3357.

Orlov, D.S. (1990), Humic Acids of Soil and General Theory of Ulmification, Moscow State Univ, Moscow.

Petrik, L.F., White, R.A., Klink, M.J., Somerset, V.S., Burgers, C.L., and Fey, M.V. (2003), Utilization of south African Fly Ash to Treat Acid Coal Mine Drainage, and Production of High Quality Zeolites from the Residual Solids, In: International Ash Utilization Symposium, University of Kentucky, USA.

Polat, M., Eli, L., Ithamar, P., and Haim, C. (2002), Chemical neutralization of acidic wastes using fly ash in Israel, Journal of Chemical Technology \& Biotechnology, 77, 377-81.

Potgieter-Vermaak, S.S., Potgieter, J.H., Monama, P., and Van Grieken, R., (2006), Comparison of limestone, dolomite and fly ash as pre-treatment agents for acid mine drainage, Minerals Engineering, 19,454-462.

Pradhan, A., and Deshmukh, J.K. (2008), Utilization of fly ash for treatment of acid mine water, Journal of Environmental Research and Development, 3,137-142.

Puls, R.W., Paul, C.J., and Powell, R.M. (1997), The application of in situ permeable reactive (zero-valent iron) barrier technology for the remediation of chromate-contaminated groundwater: a field test, Applied Geochemistry, 14, 9891000.

Ríos, C.A., Williams, C.D., and Roberts, C.L. (2008), Removal of heavy metals from acid mine drainage (AMD) using coal fly ash, natural clinker and synthetic zeolites, Journal of Hazardous Materials, 156, 23-35.

Reynolds, K. (2004), The use of fly ash for the control and treatment of acid mine drainage, In: Proceedings of the Water Institute of Southern Africa (WISA). Biennial Conference. Cape Town, South Africa.

Sahoo, P.K., Tripathy, S., Equeenuddin, Sk. Md., and Panigrahi, M.K. (2012), Geochemical characteristics of coal mine discharge vis-à-vis behavior of rare earth elements at Jaintia Hills coalfield, northeastern India, Journal of Geochemical Exploration, 112, 235-243.

Sahoo, P.K., Tripathy, S., and Panigrahi, M.K., Equeenuddin Sk. Md. (2013), Evaluation of the use of an alkali modified fly ash as a potential adsorbent for the removal of metals from acid, Applied Water Science, 3, 567-576.

Sastri, V.S. (1979), Reverse Osmosis separation of metal ions in acid mine-water, Separation Science and Technology, 14, 711-719.

Shokes, T.E., and Moller, G. (1999), Removal of dissolved heavy metals from acid rock drainage using iron metal, Environmental Science and Technology, 33, 282-287.

Simate, G.S., and Ndlovu, S. (2014), Acid mine drainage: Challenges and opportunities, Journal of Environmental Chemical Engineering, 2, 1785-1803.

Skousen, J. (2002), A brief overview of control and treatment technologies for acid mine drainage, In: Proceedings of National Mtg of the American Society of Mining and Reclamation, pp 879-899.

Skousen, J., Hilton, T., and Faulkner, B. (1996), Overview of acid mine drainage treatment with chemicals, Green Lands, 26:36-45.

Skousen, J., Rose, A., Geidal, G., Foreman, J., Evans, R., and Heillier, W. (1998), Handbook of Technologies for Avoidance and Remediation of Acid Mine Drainage, The National Mine Land Reclamation Center, Morgantown, West Virginia.

Skousen, J.G., Sexstone, A., Ziemkiewicz, P.F. (2000), Reprinted from Reclamation of Drastically Disturbed Lands. American Society of Agronomy and American Society for Surface Mining and Reclamation, Agronomy No. 41. 1-42.

Skousen, J., Rose, A., Geidel, G., Foreman, J., Evans, R., and Hellier, W. (1998), Handbook of Technologies for Avoidance and Remediation of Acid Mine Drainage, National Mine Land Reclamation Center, Morgantown.

Sinha, A., Bose, P. (2009) Interaction of chloroethanes and chloroethenes with unrusted and rusted high carbon iron filings, Environmental Engineering Science, 26 (1), 61-70.

Somerset, V., Petrik, L., Iwuoha, E. (2008), Alkaline hydrothermal conversion of fly ash precipitates into zeolites 3 : The removal of mercury and lead ions from wastewater, Journal of Environmental Management, 87, 125-131.

Taylor, J., Pape, S., and Murphy, N. (2005), A summary of passive and active treatment technologies for acid and metalliferous drainage (AMD), In: Proceedings of the 5th Australian Workshop on Acid Drainage, Earth Systems, Australian Centre for Minerals Extension and Research, Fremantle, Australia, pp 1-49.

Tiwary, R.K. (2001), Environmental Impact of Mining on Water Regime and its Management, Water, Air, and Soil Pollution, 132, 185-199.

U.S. Environmental Protection Agency (1995), Mining Metallic Ores and Minerals, Technical Support Document, International Training Workshop, Principles of Environmental Enforcement.

Vadapalli, V.R.K., Gitari, W.M., Ellendt, A., Petrik, L.F., and Balfour, G. (2010), Synthesis of zeolite-P from coal fly ash derivative and its utilisation in mine-water remediation, South Africa Journal of Science, 106, 1-7.

Weisener, C.G., Sale, K.S., Smyth, D.J.A., and Blowes, D.W. (2005), Field Column Study Using Zerovalent Iron for 
Mercury Removal from Contaminated Groundwater, Environmental Science and Technology, 39, 6306-6312.

Wilkin, R.T., and McNeil, M.S. (2003), Laboratory evaluation of zero-valent iron to treat water impacted by acid mine drainage, Chemosphere, 53, 715-725.

Zaki, N.G., Khattab, I.A., and Abd El-Monem, N.M. (2007), Removal of some heavy metals by CKD leachate, Journal of Hazardous Materials, 147, 21-27.

Zhong, C.M., Zhen-Liang, Xu., Fang, X.H., and Cheng, L. (2007), Treatment of acid mine drainage (AMD) by ultra-lowpressure reverse osmosis and nanofiltration, Environmental Engineering Science, 24, 1297-1306.

Ziemkiewicz, P.F., and Skousen, J.G. (1998), The use of steel slag in acid mine drainage treatment and control, In: 19th Annual West Virginia Surface Mine Drainage Task Force Symposium, 28, 46-56. 